


\section{Groepskraamsysteem: ontwikkeling van zeugen, biggen en vleesvarkens bij spenen op 4 of 9 weken leeftijd}

Group housing for lactating sows: development of pigs raised in a multi-suckling system and weaned abruptly at an age of 4 weeks or gradually at an age of 9 weeks

C.M.C. van der Peet-Schwering ${ }^{1}$, S.E. van Nieuwamerongen ${ }^{2}$, J.E. Bolhuis ${ }^{2}$, G.P. Binnendijk ${ }^{1}$, N.M. Soede ${ }^{2}$

${ }^{1}$ Wageningen Livestock Research

${ }^{2}$ Wageningen Universiteit, Adaptatiefysiologie

Dit onderzoek is uitgevoerd als onderdeel van de publiek-private samenwerking (PPS) "Samenwerkende Varkenshouderijketen" met financiering vanuit de topsector Agri\&Food.

Wageningen Livestock Research

Wageningen, februari 2017 
C.M.C. van der Peet-Schwering, S.E. van Nieuwamerongen, J.E. Bolhuis, G.P. Binnendijk, N.M. Soede. 2017. Groepskraamsysteem: ontwikkeling van zeugen, biggen en vleesvarkens bij spenen op 4 of 9 weken leeftijd. Wageningen Livestock Research, Livestock Research Rapport 1012.

Samenvatting NL: Op Varkens Innovatie Centrum Sterksel is het effect onderzocht van twee speenstrategieën op de ontwikkeling (groei, voeropname, gezondheid, spelgedrag en beschadigend gedrag) van biggen uit een groepskraamsysteem met vijf zeugen en haar biggen. In de ene groep werden de biggen abrupt gespeend op 4 weken leeftijd (A4). In de andere groep werden de biggen geleidelijk gespeend op 9 weken leeftijd door toepassing van intermittent suckling (IS9). De A4 biggen bleven na spenen in een groep van 35 bij elkaar in een verrijkt biggenhok. Op een leeftijd van 9 weken zijn zowel de A4 als de IS9 biggen opgelegd in verrijkte vleesvarkenshokken voor 35 dieren. De bevindingen van het onderzoek bij de zeugen, biggen en vleesvarkens zijn beschreven in dit rapport.

Trefwoorden: groepskraamsysteem, multi-suckling, intermittent suckling, geleidelijk spenen, technische resultaten, gedrag, biggen, vleesvarkens

Keywords: group farrowing, multi-suckling, intermittent suckling, gradual weaning, performance, behavior, piglets, growing-finishing pigs

Dit rapport is gratis te downloaden op http://dx.doi.org/10.18174/409672 of op www. wur. nl/livestockresearch (onder Wageningen Livestock Research publicaties).

\section{(C) 2017 Wageningen Livestock Research}

Postbus 338, 6700 AH Wageningen, T 03174839 53, E info.livestockresearch@wur.nl, www.wur.nl/livestock-research. Wageningen Livestock Research is onderdeel van Wageningen University \& Research.

Wageningen Livestock Research aanvaardt geen aansprakelijkheid voor eventuele schade voortvloeiend uit het gebruik van de resultaten van dit onderzoek of de toepassing van de adviezen.

Alle rechten voorbehouden. Niets uit deze uitgave mag worden vermenigvuldigd en/of openbaar gemaakt worden door middel van druk, fotokopie, microfilm of op welke wijze dan ook zonder voorafgaande toestemming van de uitgever of auteur. onderzoeksopdrachten zijn de Algemene Voorwaarden van de Animal Sciences Group van toepassing. Deze zijn gedeponeerd bij de Arrondissementsrechtbank Zwolle. 


\section{Inhoud}

$\begin{array}{lr}\text { Woord vooraf } & 5\end{array}$

$\begin{array}{ll}\text { Samenvatting } & 7\end{array}$

$\begin{array}{ll}\text { Summary } & 9\end{array}$

$1 \quad$ Inleiding $r$

$2 \quad$ Materiaal en methode $r$

$\begin{array}{lll}2.1 & \text { Proeflocatie en proefomvang } & 12\end{array}$

$\begin{array}{lll}2.2 & \text { Proefbehandelingen } & 12\end{array}$

$\begin{array}{lll}2.3 & \text { Proefopzet en proefindeling } & 12\end{array}$

$\begin{array}{lll}2.4 & \text { Huisvesting en klimaat } & 13\end{array}$

\begin{tabular}{ll}
2.5 & Voeding en drinkwaterverstrekking \\
\hline
\end{tabular}

$\begin{array}{ll}2.6 & \text { Berigheidscontrole en inseminatie tijdens IS } \\ 2.7 & 16\end{array}$

$\begin{array}{ll}2.7 & \text { Waarnemingen }\end{array}$

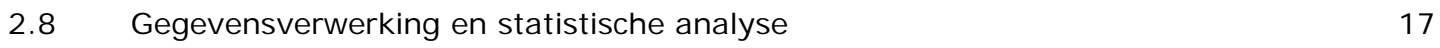

3 Resultaten $r$

$\begin{array}{lll}3.1 & \text { Zeugen in kraamstal } & 19\end{array}$

3.1.1 Voerverbruik, gewicht en spekdikte 19

3.1.2 Aantal geboren biggen en uitval biggen tot 4 weken na werpen 19

3.1.3 Inseminatie tijdens lactatiebronst en resultaten volgende worp 20

$\begin{array}{lll}3.2 & \text { Technische resultaten biggen en vleesvarkens } & 21\end{array}$

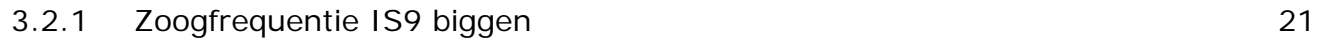

3.2.2 Technische resultaten biggen 4 tot 9 weken leeftijd 22

3.2.3 Uitval en veterinaire behandelingen biggen 4 tot 9 weken leeftijd 22

3.2.4 Technische resultaten en slachtkwaliteit vleesvarkens 23

3.2.5 Uitval en veterinaire behandelingen vleesvarkens 25

3.3 Huid-, staart- en oorbeschadigingen en diarreescore bij biggen en vleesvarkens 26

$\begin{array}{lll}3.4 & \text { Gedrag en activiteit biggen en vleesvarkens } & 27\end{array}$

4 Discussie $\quad 30$

$5 \quad$ Conclusies $\quad 34$

$\begin{array}{ll}\text { Literatuur } & 35\end{array}$

Bijlage 1 Protocol beschadigingen biggen 37

$\begin{array}{lll}\text { Bijlage } 2 & \text { Protocol gedragswaarnemingen } & 38\end{array}$ 


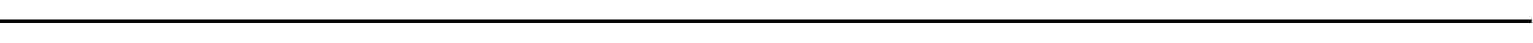




\section{Woord vooraf}

In opdracht van het Ministerie van Economische Zaken doet Wageningen University \& Research onderzoek naar groepshuisvesting van kraamzeugen en hun biggen. Groepshuisvesting tijdens de lactatie past in het stimuleren van duurzame stalsystemen in de varkenshouderij en sluit aan op groepshuisvesting tijdens de dracht. Momenteel zijn er geen praktijkbedrijven met een groepshuisvestingssysteem voor kraamzeugen omdat er - naast een aantal succesfactoren- ook meerdere risicofactoren zijn die commerciële toepassing nog niet haalbaar maakt.

In 2013 is een literatuuronderzoek uitgevoerd naar de succes- en risicofactoren van groepshuisvesting van kraamzeugen en hun biggen in vergelijking met individuele huisvesting van kraamzeugen in kraamboxen en met los werpen in individuele werphokken. Hiervoor is een inventarisatie gemaakt van wetenschappelijke literatuur en praktijkervaringen in binnen- en buitenland. De resultaten van de inventarisatie zijn gebruikt voor de ontwikkeling van een groepskraamsysteem op Varkens Innovatie Centrum (VIC) in Sterksel. In de pilotstal is in 2013 gewerkt aan een verbetering van het management en de lay-out van het systeem, met een focus op de periode rondom werpen en na het groeperen van de tomen. In 2014 is een onderzoek uitgevoerd naar de ontwikkeling (groei, voeropname, gezondheid en gedrag) van biggen die opgegroeid zijn in een groepskraamsysteem en na spenen gehuisvest zijn in een verrijkt hok in een groep van 40 biggen in vergelijking met de ontwikkeling van biggen die opgegroeid zijn een traditioneel kraamhok en na spenen als toom bij elkaar zijn gehouden in een gangbaar hok met 10 biggen. De bevindingen van dat onderzoek zijn beschreven in het rapport "Groepskraamsysteem: analyse van de ontwikkeling van zeugen, biggen en vleesvarkens" (Van der Peet-Schwering et al., 2015) en in het artikel "Development of piglets raised in a new multi-litter housing system vs. conventional single-litter housing until 9 weeks of age" (Van Nieuwamerongen et al., 2015).

In 2015 lag de focus op de ontwikkeling van biggen tijdens een verlengde zoogperiode en stimulatie van lactatiebronsten tijdens de verlengde zoogperiode. In een hiervoor nieuw gebouwde stal zijn eerst 4 oefenrondes gedraaid om ervaring op te doen met intermittent suckling (IS) bij zeugen en biggen in een groepskraamsysteem. Hieruit bleek dat een groot deel van de zeugen berig wordt na IS en geïnsemineerd kan worden tijdens de lactatie. Daarnaast bleek dat verlenging van de zoogperiode mogelijk is onder de voorwaarde dat de zeugen zich af kunnen zonderen van de biggen.

In de aansluitende 5 rondes is vervolgens een systeemvergelijking gemaakt ten aanzien van de ontwikkeling van de biggen uit een groepskraamsysteem met een zoogperiode van 4 weken (controlegroep) of met een verlengde zoogperiode van 9 weken, IS en bronststimulatie en insemineren van de zeugen tijdens de lactatie (proefgroep). De focus lag hierbij op verschillen op de langere termijn (tijdens de vleesvarkensfase). De bevindingen van dit onderzoek zijn beschreven in dit rapport.

Het project wordt begeleid door een stakeholdersgroep die bestaat uit afgevaardigden van het Ministerie van Economische Zaken, LTO, NVV, Dierenbescherming, KNMvD, DAC de Peelhorst, Topigs Norsvin en Wageningen UR Livestock Research. Het projectteam bedankt de stakeholders voor hun constructieve inhoudelijke bijdrage aan het project.

Het projectteam

Carola van der Peet-Schwering

Sofie van Nieuwamerongen

Nicoline Soede

Liesbeth Bolhuis 
6 | Wageningen Livestock Research Rapport 1012 


\section{Samenvatting}

Op Varkens Innovatie Centrum Sterksel is het effect onderzocht van twee speenstrategieën op de ontwikkeling (groei, voeropname, gezondheid, spelgedrag en beschadigend gedrag) van biggen uit een groepskraamsysteem met vijf zeugen en haar biggen. In de ene groep werden de biggen abrupt gespeend op 4 weken leeftijd (A4). In de andere groep werden de biggen geleidelijk gespeend op 9 weken leeftijd door toepassing van intermittent suckling (IS9). In de IS9 groep werden de zeugen van dag 28 t/m dag 34 na werpen 10 uur per dag van de biggen gescheiden door ze naar de aangrenzende IS-ruimte te brengen. In de IS-ruimte hadden de zeugen beercontact om de berigheid op te wekken. Van dag 35 tot dag 63 na werpen konden de zeugen zich vrijwillig van de biggen afzonderen door naar de IS-ruimte te gaan. De biggen hadden geen toegang tot de IS-ruimte. De A4 biggen bleven na spenen in een groep van 35 bij elkaar in een verrijkt biggenhok. Op een leeftijd van 9 weken zijn zowel de A4 als de IS9 biggen opgelegd in verrijkte vleesvarkenshokken voor 35 dieren. Het onderzoek omvatte in totaal vijf ronden van elk 10 zeugen. Per ronde werden twee groepen van elk vijf zeugen (pariteit 2 tot en met 5 ) een week voor werpen opgelegd in twee groepskraamafdelingen. De biggen zijn gevolgd vanaf geboorte tot afleveren naar het slachthuis.

De belangrijkste conclusies uit dit onderzoek zijn:

- Zowel in de A4 als de IS9 groep is een hoog percentage (ca. 23\%) van de biggen uitgevallen van werpen tot vier weken na werpen. Circa $60 \%$ hiervan is doodgelegen door de zeug in de eerste dagen na werpen. De overige biggen zijn uitgevallen vanwege laag geboortegewicht, spreidzit en diverse redenen. De meeste biggen zijn uitgevallen in het werphok voor het groeperen van de biggen (3,0 biggen per toom); 0,5 big per toom is uitgevallen na het groeperen van de tomen.

- De zeugen uit de A4 groep zijn allemaal binnen een week na spenen berig geworden en geïnsemineerd. Van de zeugen uit de IS9 groep is $79 \%$ ( $20 \%$ in ronde $1,95 \%$ in ronde $2 \mathrm{t} / \mathrm{m}$ 5 ) binnen een week na de start van de verplichte IS berig geworden. Na ronde 1 is het aantal uren beercontact per dag gewijzigd. Het afbigpercentage van $1^{\text {ste }}$ inseminatie van de zeugen die geïnsemineerd zijn tussen dag 28 en dag 35 na werpen was $90 \%$ in zowel de A4 als de IS9 groep. Het totaal aantal geboren biggen in de volgende worp in de A4 en IS 9 groep was respectievelijk 17,4 en 17,7. Het spenen van de zeugen op 9 weken na werpen in combinatie met IS en inseminatie tijdens de lactatie heeft de reproductie resultaten van de zeugen in ronde $2 \mathrm{t} / \mathrm{m} 5$ dus niet verslechterd in vergelijking met abrupt spenen op 4 weken na werpen.

- De zoogfrequentie bij de IS9 biggen daalde van 26,4 zoogbeurten per 24 uur op dag 21 na werpen tot 10,1 zoogbeurten per 24 uur op dag 56 na werpen. De IS9 biggen werden dus geleidelijk gespeend.

- Het effect van spenen op de A4 biggen was in dit onderzoek groter dan het effect van IS (verplichte IS in de vijfde week na werpen en daarna vrijwillige IS, waarin de zeugen de biggen vrijwillig konden verlaten) op de IS9 biggen. Dit blijkt uit een lagere groei van dag 28 tot 33 van de A4 biggen in vergelijking met de IS9 biggen ( $179 \mathrm{vs} 305 \mathrm{~g} / \mathrm{d}$ ), een hoger percentage A4 biggen met diarree op dag 33 en dag 40 ( 33 vs 12,5\%), een hogere frequentie van belly nosing nosing (het wrijven van de buik van een ander varken via het op en neer bewegen van de snuit) bij de A4 biggen, een piek in belly nosing en in agressief gedrag op dag 41 bij de A4 biggen en een hogere frequentie van oraal manipulatief gedrag bij de A4 biggen.

- Van dag 28 tot 63 groeiden de IS9 biggen $50 \mathrm{~g} / \mathrm{d}(\mathrm{p}=0,12)$ meer dan de A4 biggen terwijl ze duidelijk minder biggenvoer opnamen (0,33 vs 0,67 kg/d). De IS9 biggen konden ook melk bij de zeug en zeugenvoer opnemen. De opname van zeugenmelk en zeugenvoer door de biggen is niet bekend. Het percentage uitgevallen biggen van dag 28 tot 63 was vergelijkbaar in de A4 en IS9 groep.

- Van dag 63 tot dag 68 namen de IS9 vleesvarkens evenveel voer op als de A4 vleesvarkens en hadden een vergelijkbare groei. Er lijkt dus geen sprake geweest te zijn van een speendip bij de IS9 vleesvarkens. Van dag 63 tot afleveren waren er geen verschillen in voeropname, groei, voederconversie en slachtkwaliteit tussen de A4 en IS9 vleesvarkens. 
- Bij de IS9 vleesvarkens was er na spenen geen piek in de frequentie van belly nosing en agressief gedrag zoals te zien was bij de A4 biggen op 14 dagen na spenen. Ook was er geen toename van oraal manipulatief gedrag. Dit duidt op minder stress als gevolg van spenen bij de IS9 dieren dan bij de A4 dieren.

- Gedurende het vleesvarkenstraject vertoonden de IS9 vleesvarkens minder oraal manipulatief gedrag en belly nosing dan de A4 vleesvarkens. Dit duidt op minder stress bij de IS9 vleesvarkens dan bij de A4 vleesvarkens. De verschillen in gedrag tussen de IS9 en A4 vleesvarkens geven aan dat de effecten van abrupt spenen op 4 weken leeftijd of geleidelijk spenen op 9 leeftijd ook op de lange termijn nog zichtbaar zijn.

Op basis van dit onderzoek kan geconcludeerd worden dat de IS9 varkens beter konden omgaan met de overgangen op 4 en 9 weken leeftijd dan de A4 varkens. Bij de IS9 varkens was er geen sprake van een speendip en ze vertoonden minder gedrag dat wijst op stress als gevolg van spenen (zoals oraal manipulatief gedrag en belly nosing). Op basis van dit onderzoek lijkt geleidelijk spenen op 9 weken leeftijd in groepskraamsystemen een goede strategie om de speendip te voorkomen en het gedrag van de biggen en vleesvarkens te verbeteren. Het doodliggen van biggen in het werphok in de eerste dagen na geboorte is een belangrijk aandachtspunt dat verder verbeterd moet worden. 


\section{Summary}

In a study at Swine Innovation Centre Sterksel the effect of two weaning procedures on the development of pigs raised in a multi-suckling (MS) system with five sows and their litters was studied. One MS group was weaned abruptly at 4 weeks of age and was subsequently housed in an enriched pen in a group of 35 piglets ( 7 piglets from each litter) (A4 treatment). The other MS group was subjected to gradual weaning during a lactation period of 9 weeks, which was stimulated by forced intermittent suckling (IS) for 10 hours/day during the fifth week of lactation, followed by a 4week period in which the sows could voluntarily get away from their piglets (IS9 treatment). During forced IS, sows had contact with a boar in the IS area to stimulate lactational oestrus and ovulation in the sows. Piglets had no access to the IS area. At 9 weeks of age, pigs from both treatments were relocated to a finishing unit, where they were housed in enriched pens in a group of maximum 35 pigs per treatment. Five consecutive batches of 10 sows and their litters were studied. Pigs were followed from birth till delivery to the slaughter house.

The main conclusions are:

- Mortality in the first four weeks after birth was $23 \%$ in both treatments. About $60 \%$ of these piglets were crushed by the sow. Most piglets were culled in the farrowing pen (about 3.0 piglets per litter) before grouping of the litters at day 8 after birth; 0.5 piglet per litter died after grouping of the litters.

- $\quad$ All A4 sows showed oestrus and were inseminated within a week after weaning. $79 \%$ of the IS sows ( $20 \%$ in batch $1,95 \%$ in batch 2 to 5 ) showed oestrus and were inseminated within a week after the start of IS. After batch 1, the hours per day with boar contact were changed. Farrowing rate from first insemination was $90 \%$ in both treatments. The number of total born piglets in the next litter was 17.4 and $\mathbf{1 7 . 7}$ in the A4 and IS9 sows, respectively. Gradually weaning of the sows at 9 weeks after farrowing in combination with insemination during lactation has not impaired reproductive performance of the sows in batch 2 to 5 compared with abruptly weaning at 4 weeks after farrowing.

- $\quad$ Nursing frequency in the IS9 piglets gradually declined from 26.4 nursing bouts per 24 hours on day 21 after farrowing to 10.1 nursing bouts per 24 hours on day 56.

- Weaning had a more profound impact for the A4 piglets than IS and sow-initiated separation did for the IS9 pigs, demonstrated by a lower weight gain between day 28 to 33 (179 vs 305 $\mathrm{g} / \mathrm{d}$ ), a higher percentage of piglets with diarrhoea on day 33 and 40, a higher level of belly nosing, a distinct peak in belly nosing and aggression on day 41 and a higher level of oral manipulative behaviour.

- $\quad$ Between day 28 to 63, IS9 piglets eat less weaner diet and pre-starter diet than A4 piglets ( 0.33 vs $0.67 \mathrm{~kg} / \mathrm{d})$ but grew $50 \mathrm{~g} / \mathrm{d}(\mathrm{p}=0.12)$ faster than A4 piglets. IS9 piglets could also drink milk from the sow and eat from the sow feed. The intake of sow milk and sow feed by the piglets is not known. Mortality of the piglets between day 28 to 63 was similar in the A4 and IS9 treatment.

- $\quad$ For IS9 pigs, weaning seemed to have less impact than for A4 piglets. Feed intake and daily gain in the first 5 days after transition to the finishing unit were similar in IS9 and A4 pigs.

- The performance and slaughter quality of the growing and finishing pigs was similar in the A4 and IS9 treatment.

- $\quad$ The IS9 pigs did not show a peak in belly nosing and aggressive behaviour post weaning as was observed in the A4 pigs 14 days post weaning. This indicates less stress resulting from weaning in the IS9 pigs than in the A4 pigs.

- During the growing-finishing phase, IS9 pigs showed less damaging oral manipulation and belly nosing than A4 pigs, indicating a less stressed state of the IS9 pigs. It seems that IS9 pigs coped better with both transitions than A4 pigs and that the gradual weaning treatment had long-term beneficial effects, particularly concerning behaviour. 
Overall it can be concluded that IS9 pigs coped better with the transitions at 4 and 9 weeks of age than A4 pigs. IS9 pigs did not show a post weaning growth check, nor behavioural indicators of having difficulty coping with the post weaning situation. Additionally, long-term effects of the gradual weaning procedure were found. Crushing of the piglets in the farrowing pen in the first few days after birth is an important issue that needs to be improved. 


\section{$1 \quad$ Inleiding}

Groepshuisvesting van zeugen tijdens de dracht is sinds 2013 verplicht in de EU (Richtlijn 2001/88/EG). Tijdens de lactatie worden zeugen echter meestal individueel gehuisvest in een kraamhok. Groepshuisvesting tijdens de lactatie past in het stimuleren van duurzame stalsystemen in de varkenshouderij en sluit aan op groepshuisvesting tijdens de dracht. Bij groepshuisvesting tijdens de lactatie komen de zeugen een aantal dagen voor afbiggen in een systeem dat bestaat uit werphokken en een multi-sucklingruimte (MS-ruimte). Net als in een natuurlijke situatie, verlaten de zeugen rondom het afbiggen voor een korte periode de zeugengroep om af te biggen in een eigen 'los' kraamhok met nestbouwmateriaal. Na afbiggen mogen de zeugen terug naar de naastgelegen ruimte (MS ruimte) zodat de sociale structuur van de zeugengroep zoveel mogelijk blijft bestaan. De biggen mogen naar de MS-ruimte op het moment dat de zeug-big contacten sterk genoeg zijn (dat is ca. 8 dagen na geboorte). In deze ruimte leren de biggen vast voer eten van de zeug en leren ze zich sociaal te gedragen (zeug-big en big-big).

Van Nieuwamerongen et al. (2014) gaven op basis van literatuuronderzoek aan dat een groepskraamsysteem de potentie heeft om de voeropname van biggen voor spenen te verhogen doordat de biggen van de zeugen en andere biggen kunnen leren, wat een positief effect heeft op de voeropname en groei na spenen (Oostindjer et al., 2011). Anderzijds is de biggensterfte, met name als gevolg van doodliggen, hoger in groepskraamsystemen dan in traditionele kraamhokken waarin de zeugen individueel gehuisvest zijn en in een kraambox staan.

In 2014 is op Varkens Innovatie Centrum (VIC) Sterksel de ontwikkeling (groei, voeropname, gezondheid, sociaal gedrag, spelgedrag en beschadigend gedrag) van biggen die opgegroeid zijn in een groepskraamsysteem (GHV) en na spenen gehuisvest zijn in een verrijkt hok in een groep van 40 biggen vergeleken met de ontwikkeling van biggen die opgegroeid zijn in een traditioneel kraamhok en na spenen als toom bij elkaar zijn gehouden in een gangbaar hok met 10 biggen (controle). Hieruit bleek dat de uitval van biggen (m.n. als gevolg van doodliggen) voor spenen hoger was bij de GHV biggen dan bij de controlebiggen maar dat de GHV biggen beter adapteerden na spenen (hogere voeropname en groei, meer spelgedrag en minder manipulatief gedrag) resulterend in een hoger gewicht bij opleg in de vleesvarkensstal (Van der Peet-Schwering et al., 2015).

Mogelijk kan de ontwikkeling van biggen uit een groepskraamsysteem verder verbeterd worden door ze geleidelijk te spenen op een latere leeftijd (net als in een natuurlijke situatie) in plaats van ze abrupt te spenen op een leeftijd van 4 weken. Geleidelijk spenen kan gerealiseerd worden door het toepassen van intermittent suckling (IS), waarbij de zeugen gedurende een aantal uren per dag gescheiden zijn van de biggen. Een combinatie van IS en een verlengde zoogperiode heeft een positief effect op de voeropname, groei en darmgezondheid van de biggen na spenen (Berkeveld et al., 2009). Daarbij heeft IS tijdens een verlengde zoogperiode ook effect op het gedrag van de biggen. Agressie en manipulatief gedrag, zoals het kauwen op lichaamsdelen van hokgenoten, kwamen minder voor na spenen in vergelijking met abrupt spenen op 4 weken leeftijd (Berkeveld et al., 2007).

Op VIC Sterksel is een systeemvergelijking gemaakt ten aanzien van de ontwikkeling van de biggen uit een GHV systeem bij abrupt spenen op 4 weken leeftijd (A4) of geleidelijk spenen op 9 weken leeftijd met verplichte IS tijdens de vijfde week van de lactatie en vrijwillige IS in de periode daarna (IS9). Tijdens de verplichte IS werden de zeugen gedurende 7 dagen 10 uur per dag van de biggen gescheiden door ze naar de IS-ruimte te brengen. In de IS-ruimte hadden de zeugen beercontact om de berigheid op te wekken. Berige zeugen zijn geïnsemineerd. Tijdens de vrijwillige IS (week $6 \mathrm{t} / \mathrm{m} 9$ van de zoogperiode) konden de zeugen zich vrijwillig van de biggen afzonderen door naar de ISruimte te gaan. De biggen hadden geen toegang tot de IS-ruimte. De A4 biggen bleven na spenen in een groep van 35 bij elkaar in een verrijkt hok. Op een leeftijd van 9 weken zijn zowel de A4 als de IS9 biggen opgelegd in verrijkte vleesvarkenshokken voor 35 dieren. 


\section{Materiaal en methode}

\subsection{Proeflocatie en proefomvang}

Het onderzoek is uitgevoerd op Varkens Innovatie Centrum (VIC) Sterksel in de periode januari 2015 tot en met juli 2016. In totaal zijn 50 zeugen (pariteit 2 tot en met 5) en hun biggen gevolgd. De biggen zijn gevolgd vanaf geboorte tot afleveren naar het slachthuis. Het onderzoek omvatte in totaal vijf ronden van elk 10 zeugen. Per ronde werden 2 groepen van elk vijf zeugen opgelegd in twee groepskraamafdelingen.

\subsection{Proefbehandelingen}

In het onderzoek zijn twee proefbehandelingen met elkaar vergeleken

1) Abrupt spenen op 4 weken leeftijd (A4): biggen zijn opgegroeid in een GHV systeem en zijn na spenen op een leeftijd van 4 weken gehuisvest in een verrijkt biggenopfokhok voor 35 dieren. Op 9 weken leeftijd zijn de biggen opgelegd in een verrijkt vleesvarkenshok voor 35 dieren.

2) Geleidelijk spenen op 9 weken leeftijd (IS9): biggen zijn opgegroeid in een GHV systeem en geleidelijk gespeend op 9 weken leeftijd. Op 9 weken leeftijd zijn de biggen opgelegd in een verrijkt vleesvarkenshok voor 35 dieren. Van dag 28 t/m 34 na werpen zijn de zeugen 10 uur per dag van (van 6.00 - $16.00 \mathrm{u}$ ) van de biggen gescheiden door ze naar de IS-ruimte te brengen (verplichte IS). In de IS-ruimte hadden de zeugen beercontact om de berigheid op te wekken. Berige zeugen zijn geïnsemineerd. Van dag 35 na werpen tot spenen vond vrijwillige IS plaats, waarbij de zeug kon kiezen of ze bij de biggen of in de IS-ruimte verbleef. De biggen hadden geen toegang tot de IS-ruimte.

\subsection{Proefopzet en proefindeling}

\section{Een week voor werpen tot 4 weken leeftijd}

Een week voor het werpen zijn per ronde twee groepen van vijf zeugen verplaatst naar het GHV systeem. De zeugen die bij elkaar in het GHV systeem kwamen zaten tijdens de dracht bij elkaar in dezelfde stabiele groep en hadden dezelfde verwachte werpdatum. De zeugen zijn ingedeeld op basis van pariteit. Tussen 24 en 48 uur na geboorte zijn biggen overgelegd indien nodig. Elke zeug had na overleggen evenveel biggen als het aantal functionele spenen dat ze had, met een maximum van 14 biggen per zeug. Als een zeug minder biggen dan functionele spenen had, werden er indien nodig extra biggen bijgelegd van buiten de proef. Als er binnen 24 uur na werpen nog 11 biggen of minder over waren, dan is de toom tot maximaal 14 biggen aangevuld (tenzij er minder functionele spenen waren). Indien biggen van zeugen buiten de proef werden bijgelegd kwamen de bijgelegde biggen uit een traditioneel kraamhok omdat het aantal beschikbare GHV biggen binnen het bedrijf beperkt was (slechts 10 zeugen per ronde). Bij een teveel aan biggen zijn biggen weggelegd naar zeugen buiten de proef.

\section{4 tot 9 weken leeftijd}

Gebaseerd op het gewicht op 4 weken leeftijd zijn gemiddeld 34,4 biggen (range van 33 tot 35 biggen) per ronde per behandeling geselecteerd om verder te vervolgen. Uit elke toom zijn 7 gezonde biggen geselecteerd, die qua gewicht representatief waren voor de toom. De mediaan van het gewicht van de geselecteerde biggen was vergelijkbaar met de mediaan van het gewicht van de hele toom. Biggen met zichtbare afwijkingen en zieke dieren zijn niet opgelegd. Het aantal geselecteerde beren en zeugjes per behandeling was vergelijkbaar ( $52,7 \%$ beren en $47,3 \%$ zeugjes). De geselecteerde biggen in de A4 groep zijn op 4 weken verplaatst naar een verrijkt biggenopfokhok voor 35 dieren ( 7 biggen per toom). In de IS9 groep bleven alle biggen (zowel de geselecteerde als niet geselecteerde biggen; gemiddeld 58 biggen per ronde) liggen tot spenen op 9 weken leeftijd. 


\section{Vleesvarkensstal}

De biggen in de A4 groep zijn op 9 weken leeftijd als groep overgeplaatst van het biggenopfokhok naar een verrijkt vleesvarkenshok voor 35 biggen. De geselecteerde biggen uit de IS9 groep zijn na spenen op een leeftijd van 9 weken eveneens in een verrijkt vleesvarkenshok voor 35 biggen opgelegd. De twee vleesvarkenshokken bevonden zich naast elkaar in dezelfde afdeling. Bij sterfte van A4 biggen tussen 4 en 9 weken leeftijd, konden er minder dan 35 biggen opgelegd worden in de vleesvarkensstal. In de IS9 groep zijn dan ook minder dieren opgelegd in de vleesvarkensstal, zodat het aantal opgelegde dieren per proefbehandeling hetzelfde was. Bij sterfte van IS9 biggen tussen 4 en 9 weken, is de dag voor verplaatsen naar de vleesvarkensstal een vervanger geselecteerd, zodat het aantal opgelegde dieren hetzelfde was in de A4 en IS9 groep. Gemiddeld zijn 33,2 biggen per ronde per behandeling opgelegd in de vleesvarkensstal.

\section{$2.4 \quad$ Huisvesting en klimaat}

\section{Groepskraamsysteem: werphokken en multi suckling ruimte}

Het GHV systeem had twee identieke afdelingen (Figuur 1) met aangrenzend buiten een overdekte IS ruimte. Beide afdelingen hadden vijf werphokken van $2,2 \times 3,2 \mathrm{~m}$ naast elkaar met een dichte vloer van $2,2 \times 2,2 \mathrm{~m}$ en een roostervloer van $2,2 \times 1,0 \mathrm{~m}$. Het biggennest was van $0,65 \times 1,6 \mathrm{~m}$. In het biggennest lag een kunststof vloer met noppen. Het werphok bevatte een voerbak voor de zeug en een drinknippel voor zeug en biggen. Er waren twee schuin aflopende wanden en een hek om doodliggen te voorkomen; een metalen wand van $1,1 \mathrm{~m}$ bij het biggennest, een kunststof wand van 1,1 m naast de ingang van het werphok en een uitneembaar schuin hek tegen de lange zijde. De toegang tot het werphok bestond uit een verhoging waar zeugen overheen konden stappen, maar de biggen niet. Daarnaast bevond zich een biggenluikje, waardoor de biggen van het werphok naar de gezamenlijke ruimte en omgekeerd konden lopen. In elk werphok werden bij inleg 2 jute zakken gelegd als nestbouwmateriaal. Op de maandag voor werpen werd het aantal jute zakken aangevuld tot 5 . Vanaf 2 dagen na werpen tot spenen op dag 28 werd in elk werphok dagelijks een handje (ca. 75 gram) vers lang stro verstrekt.

Aansluitend aan de werphokken bevond zich centraal een gezamenlijke multi-suckling (MS) ruimte van $11,1 \times 2,80 \mathrm{~m}$ met een betonnen ligvloer van $7,00 \times 1,80 \mathrm{~m}$, een mestruimte van $9,3 \mathrm{~m}^{2}$ (roostervloer) en een eetruimte van 3,2×3,3 m (dichte vloer). De eetruimte had vijf deels afgescheiden eetplaatsen voor de zeugen en een mee-eetruimte die alleen voor biggen toegankelijk was en die 3 ronde voerbakjes (tot 5 weken leeftijd van de biggen) en vier twee-vaks droogvoerbakken (vanaf 4 weken leeftijd van de biggen) bevatte. In de mestruimte waren twee drinknippels voor de zeugen en biggen.

Vanaf inleg tot na de geboorte van de biggen werden de zeugen van $16.30 \mathrm{u}$ tot $7.30 \mathrm{u}$ opgesloten in hun eigen werphok. Na het werpen konden ze weer onbeperkt naar de MS-ruimte. Als de jongste toom in de afdeling 8 dagen oud was, werd het schot en het biggenluikje van elk werphok verwijderd en konden de biggen de gezamenlijke ruimte en andere werphokken verkennen. Indien de spreiding in werpdata meer dan 3 dagen bedroeg, werd het groeperen over 2 dagen verdeeld. In de MS ruimte werden voor inleg 5 touwen en 5 jute zakken opgehangen. Deze werden minimaal wekelijks vervangen.

Het klimaat werd geregeld door ruimteverwarming in de controlegangen en in de afdeling. De biggennesten werden d.m.v. vloerverwarming verwarmd. Daarnaast hing er een rode lamp in de het biggennest, die maximaal 3 dagen aan was. In het werphok was vloerverwarming aanwezig onder de zeug. Deze werd niet aangezet tijdens de werpweek. Na het groeperen van de biggen werd de vloerverwarming aangezet, indien nodig. De omgevingstemperatuur werd automatisch geregistreerd.

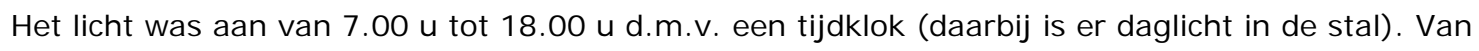
$18.00 \mathrm{u}$ tot $7.00 \mathrm{u}$ was er nachtverlichting aan (lichtslangen).

$\underline{\text { Intermittent suckling (IS) ruimte }}$

Op dag 28 na werpen werd gestart met IS. De zeugen werden van dag $28 \mathrm{t} / \mathrm{m}$ dag 34 na werpen gedurende 10 uur per dag (van 6.00 - $16.00 \mathrm{u}$ ) als groep naar de IS-ruimte (Figuur 1) gebracht. In de IS ruimte bevond zich een berenhok met beer. De zeugen konden vrij rond lopen in de IS ruimte, behalve tijdens de bronstcontrole, en konden neuscontact maken met de beer. In de IS ruimte en in de MS ruimte was een radio aan zodat de zeugen en biggen elkaar niet konden horen. De zeugen gingen via een doorgang, die ingebouwd was in de deur, naar buiten. De doorgang bestond uit een beweegbaar schot met veren waar de zeugen overheen konden stappen maar de biggen niet (het 
schot werd naar beneden geduwd als de zeug er overheen stapte). Boven het schot hingen rubberen flappen.

Van dag 35 na werpen tot spenen werd geen verplichte IS meer toegepast maar vond vrijwillige IS plaats, waarbij de zeug kon kiezen of ze bij de biggen of in de IS-ruimte verbleef. Tijdens de vrijwillige IS was er geen beer aanwezig in de IS ruimte.

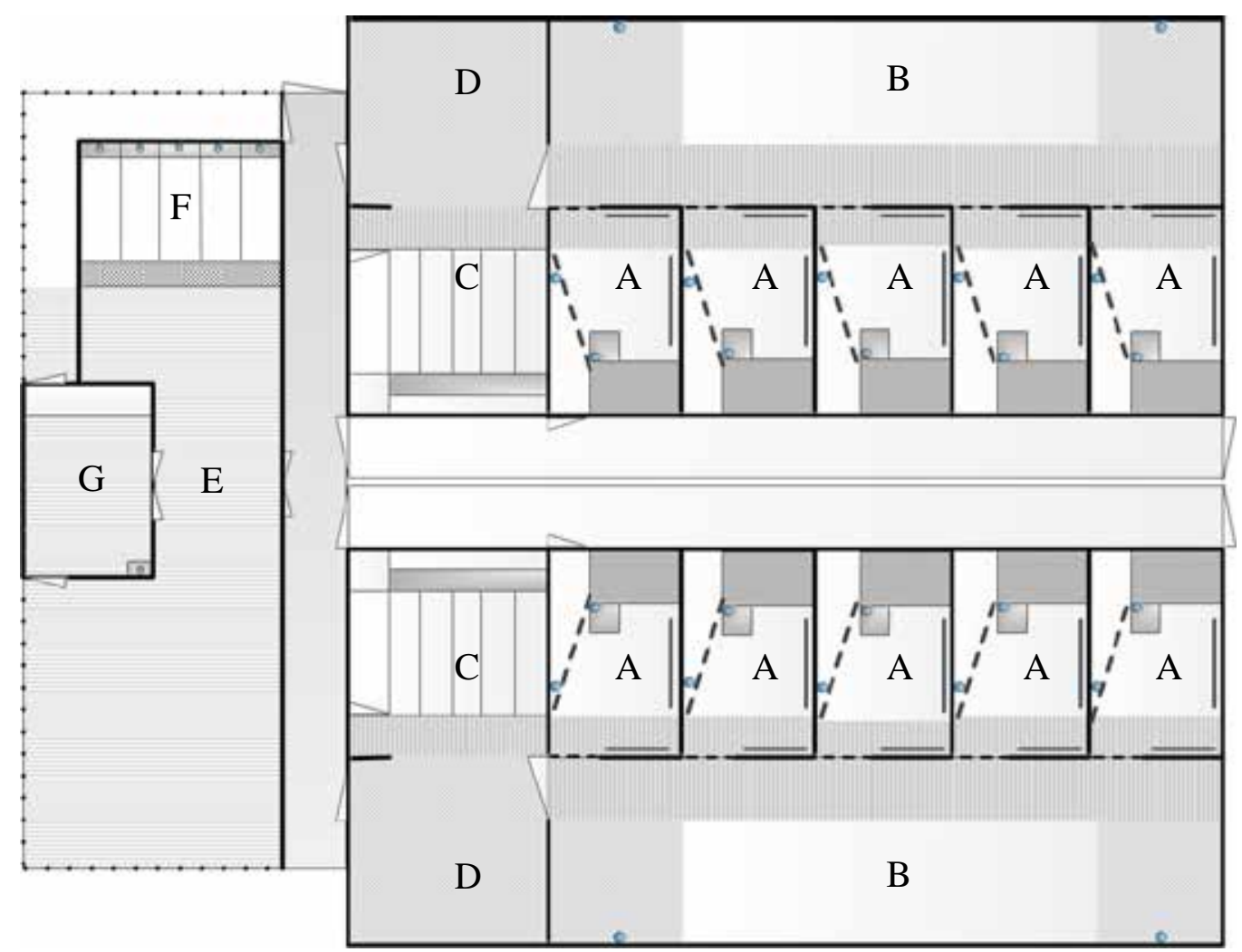

Figur 1 Indeling GHV systeem met twee indentieke afdelingen en aangrenzend buiten een overdekte IS ruimte. Iedere afdeling had vijf werphokken (A: met biggennest, voerbak zeugen, drinknippels en schuin aflopende wanden en een hek om doodliggen van biggen te voorkomen), een MS ruimte (B), een eetruimte (C) en een mestruimte (D). De IS ruimte (E) had 5 voerboxen (F) en een hok voor de beer $(G)$.
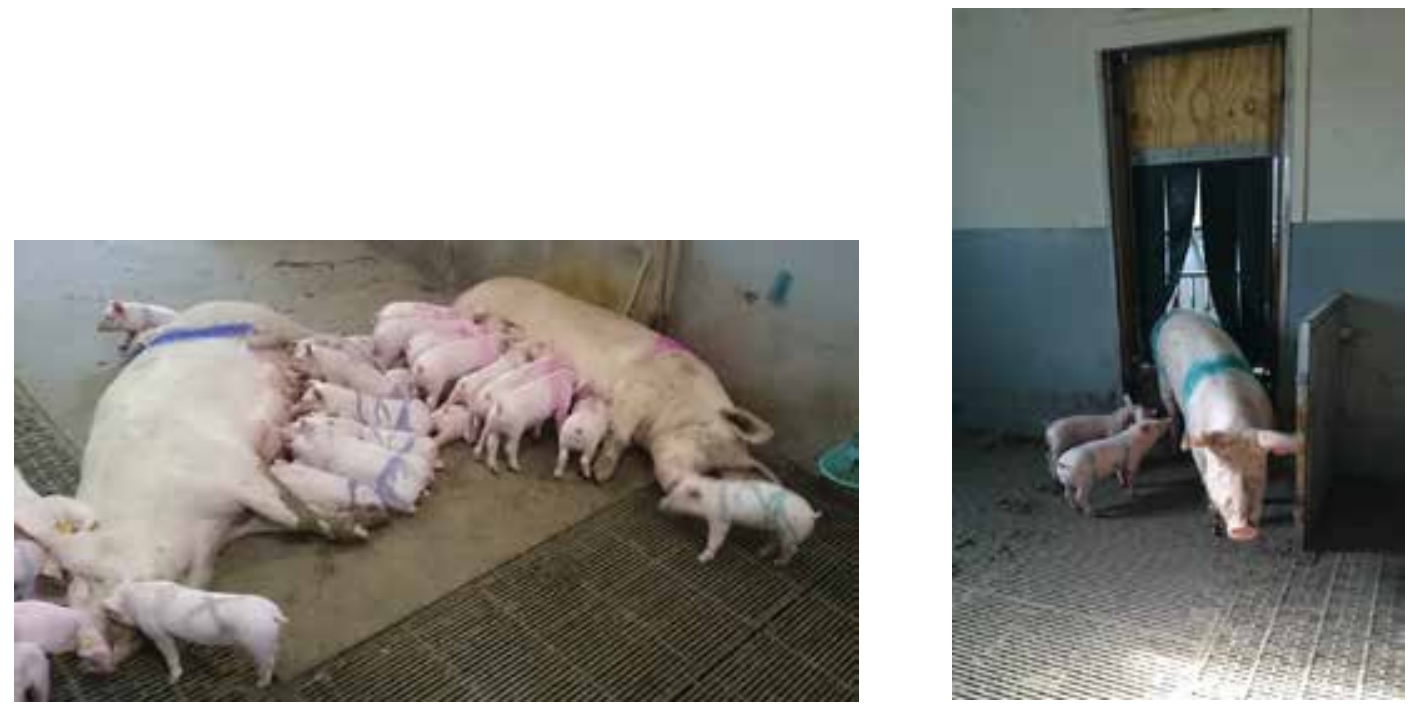

Foto Multi suckling ruimte en zeug die over het beweegbare schot stapt om van de IS ruimte naar de MS ruimte te gaan 


\section{Biggenopfokstal}

$\mathrm{Na}$ spenen op 4 weken leeftijd zijn de 33 tot 35 geselecteerde $\mathrm{A} 4$ biggen gehuisvest in een verrijkt hok van $6,18 \mathrm{~m}$ breed $\times 2,63 \mathrm{~m}$ diep $\left(0,46 \mathrm{~m}^{2} /\right.$ dier $)$. De vloer bestond vanaf de voergang gezien uit 1,37 $\mathrm{m}$ dichte betonvloer met vloerverwarming en vervolgens uit 1,36 m metalen driekant rooster. De biggen kregen tweemaal daags 4 tot 6 handjes lang stro op de dichte vloer verstrekt (hoeveelheid nam toe met de leeftijd) en hadden 4 jute zakken en 8 touwen ter beschikking als hokverrijking. De jute zakken en touwen werden minimaal wekelijks vervangen.

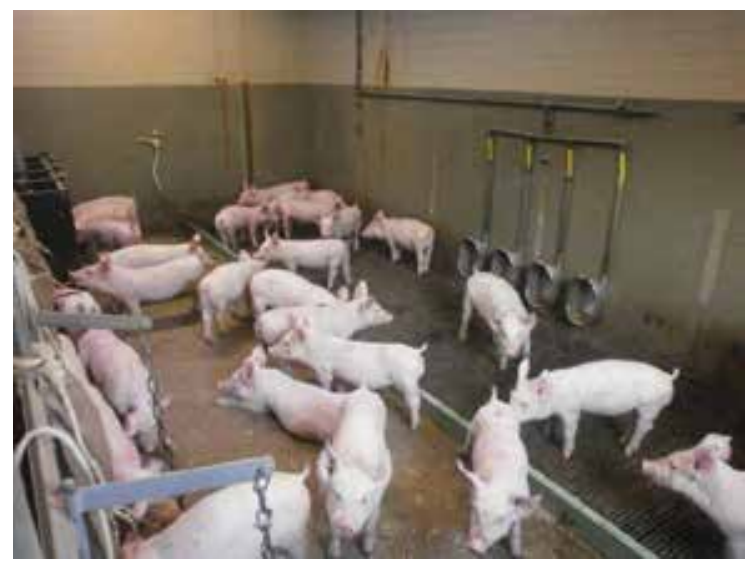

Foto Verrijkt hok voor de A4 biggen van 4 tot 9 weken leeftijd

De verse ventilatielucht in beide afdelingen werd aangevoerd via een ondergrondse luchtinlaat. De temperatuurcurve werd geleidelijk afgebouwd van 28 graden Celsius bij spenen tot 19 graden Celsius op dag 35 na spenen. Van 7.00 uur tot 18.00 uur waren de lampen aan d.m.v. een tijdklok. Van 18.00 $\mathrm{u}$ tot $7.00 \mathrm{u}$ was er nachtverlichting aan (lichtslangen).

\section{Vleesvarkensstal}

Op 9 weken leeftijd zijn zowel de A4 biggen als de geselecteerde IS9 biggen opgelegd in de Starplus stal in hokken voor 35 dieren. Gemiddeld zijn 33,2 biggen per ronde per behandeling opgelegd in de vleesvarkensstal. Elk hok had een binnen gedeelte van 6,00 $\mathrm{m} \times 5,30 \mathrm{~m}$ (81\% dichte betonvloer en $19 \%$ metalen driekant rooster) en een overdekte uitloop van $6,00 \mathrm{~m} \times 2,00 \mathrm{~m}$ (75\% betonrooster en $25 \%$ metalen driekant rooster) dat afgeschermd werd met breekgaas. De dichte betonvloer binnen was voorzien van vloerverwarming. In de Starplus werd natuurlijk geventileerd via het dak. In warme periodes konden ook de zijwanden van de stal open geklapt worden voor extra frisse lucht. Bij opleg zijn per hok 4 jute lappen en 4 touwen (die aan 2 kanten waren afgerold) opgehangen. Deze werden maximaal één keer per week vervangen, als ze versleten of bevuild waren. Tevens was de dichte vloer bij opleg ingestrooid met een laagje zaagsel en wat lang stro.

\subsection{Voeding en drinkwaterverstrekking}

\section{Zeugen}

De zeugen werden twee maal daags (ca. 8.00 uur en 16.00 uur) gevoerd volgens het standaard voerschema van VIC Sterksel. De zeugen werden vanaf inleg tot circa 10 dagen na werpen met de hand gevoerd, daarna werden ze via een voercomputer gevoerd. Vanaf inleg tot werpen kregen de zeugen $2,8 \mathrm{~kg}$ per dag. Na werpen is de voergift geleidelijk verhoogd tot 7,5 $\mathrm{kg}$ voer per dag. Als de zeugen meer voer op konden nemen dan 7,5 kg kregen ze meer voer verstrekt.

De zeugen werden voor werpen 's middags in hun eigen werphok gevoerd in een voertrog. 's Ochtends voor werpen en 's ochtends en 's middags na werpen werden de zeugen op de vloer in voerboxen in de gezamenlijke eetruimte gevoerd, tenzij een zeug na het werpen het werphok niet uit wilde. De zeug werd dan in het eigen werphok gevoerd. Na groeperen van de tomen konden de biggen mee eten met de zeugen rond de voerboxen. Vanaf start IS tot spenen werden de zeugen 's ochtends in voerligboxen in de IS-ruimte (buiten) gevoerd en 's middags in voerboxen in de gezamenlijke eetruimte (binnen). Tijdens de verplichte IS werden ze 's ochtends om $6.00 \mathrm{u}$ en 's middags om 16.30 u gevoerd. Tijdens de vrijwillige IS werden ze 's ochtends om $8.00 \mathrm{u}$ en 's middags om $16.00 \mathrm{u}$ gevoerd. Voor het verstrekken van het voer werd een geluidssignaal gegeven (fietsbel). De zeugen kregen lactovoer ( $\mathrm{EW}=1,08$; ruw eiwit $=149 \mathrm{~g} / \mathrm{kg}$; darmverteerbaar lysine $=7,6 \mathrm{~g} / \mathrm{kg}$ ) verstrekt. De 
zeugen hadden onbeperkt beschikking over drinkwater via drinknippels in de werphokken en drinkbakjes in de MS-ruimte.
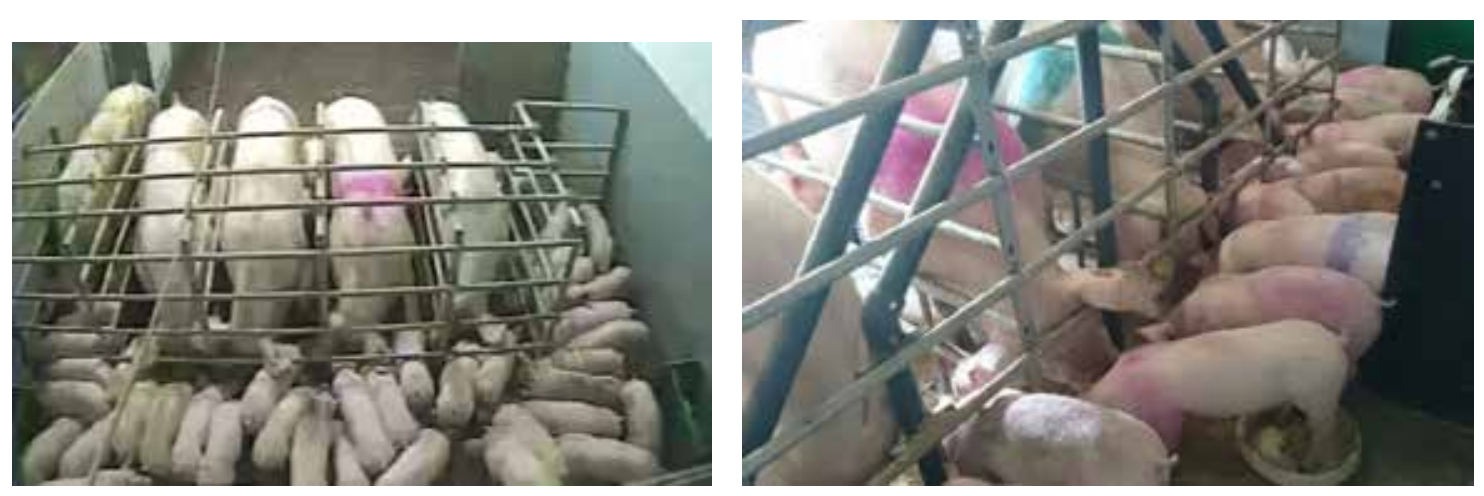

Foto Voeren van zeugen en biggen

\section{Biggen 0 tot 9 weken leeftijd}

De biggen kregen vanaf 2 dagen na de geboorte $\mathrm{XL}$ korrel verstrekt tot 3 dagen nadat alle tomen gegroepeerd waren. Na groeperen konden de biggen mee eten met de zeugen rond de voerboxen. Daarnaast kregen ze in hun eigen eetruimte vanaf een leeftijd van 12 dagen een pre-starter ( $E W=$ 1,32; ruw eiwit $=175 \mathrm{~g} / \mathrm{kg}$; darmverteerbaar lysine $=11,7 \mathrm{~g} / \mathrm{kg}$ ) verstrekt. Op dag 21 en 22 werd speenvoer bij de pre-starter ingemengd, waarna de biggen vanaf dag $23 \mathrm{t} / \mathrm{m}$ dag 42 alleen speenvoer $(\mathrm{EW}=1,13$; ruw eiwit $=160 \mathrm{~g} / \mathrm{kg}$; darmverteerbaar lysine $=9,9 \mathrm{~g} / \mathrm{kg}) \mathrm{kregen}$. Daarna zijn ze in drie dagen geleidelijk overgeschakeld op biggenopfokkorrel ( $E W=1,10$; ruw eiwit $=156 \mathrm{~g} / \mathrm{kg}$; darmverteerbaar lysine $=9,4 \mathrm{~g} / \mathrm{kg}$ ), dat ze tot opleg in de vleesvarkensstal op dag $63 \mathrm{kregen}$. Tot vijf weken leeftijd werd het voer verstrekt in drie ronde voerbakjes, die tweemaal daags bijgevuld werden. Daarnaast werden ze vanaf vier weken leeftijd onbeperkt gevoerd via vier twee-vaks droogvoerbakken die tweemaal daags (rond 8.00 en $16.00 \mathrm{u}$ ) werden bijgevuld.

De biggen hadden onbeperkt beschikking over drinkwater via drinknippels in de werphokken en drinkbakjes in de MS-ruimte.

\section{Vleesvarkensstal}

De vleesvarkens kregen vijf weken startvoer verstrekt $(E W=1,14$; ruw eiwit $=169 \mathrm{~g} / \mathrm{kg}$; darmverteerbaar lysine $=10,3 \mathrm{~g} / \mathrm{kg}$ ) daarna vier weken groeivoer $(\mathrm{EW}=1,10$; ruw eiwit $=148 \mathrm{~g} / \mathrm{kg}$; darmverteerbaar lysine $=7,9 \mathrm{~g} / \mathrm{kg}$ ) en vervolgens tot afleveren eindvoer ( $\mathrm{EW}=1,08$; ruw eiwit $=145$ $\mathrm{g} / \mathrm{kg}$; darmverteerbaar lysine $=7,4 \mathrm{~g} / \mathrm{kg}$ ). De voeroverschakelingen vonden abrupt plaats. Het voer werd onbeperkt verstrekt via vier één-vaks droogvoerbakken per hok. Naast het mengvoer kregen de dieren dagelijks lang stro en snijmaïs verstrekt. De totale dagelijks verstrekte hoeveelheid stro nam toe van 1 tot $3 \mathrm{~kg}$ per hok. De dagelijks verstrekte hoeveelheid snijmaïs nam toe van 6 tot $18 \mathrm{~kg}$ per hok. Drinkwater was in alle hokken onbeperkt beschikbaar via een drinkbakjes in de buitenuitloop.

\subsection{Berigheidscontrole en inseminatie tijdens IS}

Tijdens dag 1 en 2 van de verplichte IS liep de zoekbeer 2 × 1 u per dag tussen de zeugen. De overige 8 uur dat de zeugen in de IS-ruimte aanwezig waren, zat de beer in het berenhok. In ronde 1 was de beer tijdens de verplichte IS continue aanwezig in de IS-ruimte. In ronde $2 \mathrm{t} / \mathrm{m} 5$ was de beer alleen tijdens de eerste twee dagen van de verplichte IS continue in de IS-ruimte aanwezig. Op dag 3 en 4 van de verplichte IS zat de beer 's ochtends van $6.00 \mathrm{u}$ tot $9.00 \mathrm{u}$ in het berenhok. De overige uren was hij niet aanwezig in de IS-ruimte. Van dag $5 \mathrm{t} / \mathrm{m} 7$ zat de beer 's ochtends van $6.00 \mathrm{u}$ tot $9.00 \mathrm{u}$ en 's middags van $13.00 \mathrm{u}$ tot $16.00 \mathrm{u}$ in het berenhok. Tussen $9.00 \mathrm{u}$ en $13.00 \mathrm{u}$ was de beer niet aanwezig in de IS-ruimte. Op alle dagen tijdens de verplichte IS werd twee keer per dag (8.45 u en $15.45 \mathrm{u}$ ) de berigheid van de lacterende zeugen gecontroleerd door de zoekbeer voor de boxen langs te laten lopen. 24 uur na de eerste stareflex werden de zeugen geïnsemineerd met een commerciële $\mathrm{KI}$ dosis en 24 uur later werden ze, indien nodig, nog een keer geïnsemineerd. 


\subsection{Waarnemingen}

Tijdens het onderzoek zijn de volgende waarnemingen uitgevoerd bij de zeugen, biggen en vleesvarkens:

\section{Zeugen:}

- Gewicht en spekdikte van de zeugen bij inleg in de kraamstal, dag 28 na werpen (spenen van A4 biggen en start IS van IS9 biggen) en 63 dagen na werpen (alleen IS9 zeugen). De spekdikte is bepaald op de P2-plaats (ter hoogte van de laatste rib, $5 \mathrm{~cm}$ links van de mediaan).

- Aantal levend en dood geboren biggen, aantal overgelegde biggen, aantal uitgevallen biggen en aantal gespeende biggen.

- Voeropname zeugen: de verstrekte hoeveelheid voer van inzet kraamstal tot werpen, van werpen tot spenen (A4 groep: dag 28 na werpen; IS9 groep: dag 63 na werpen) is per groep van vijf zeugen genoteerd. Na het groeperen konden ook de biggen mee eten van het zeugenvoer.

- Datum berigheid, inseminatiedatum en afbigpercentage van $1^{\text {ste }}$ inseminatie.

- Aantal levend en dood geboren biggen in de volgende worp.

\section{Biggen en vleesvarkens:}

- Zoogfrequentie (alleen IS9 biggen) gedurende 24 uur op dag 21, 29, 35, 42, 49 en 56 na werpen. Het totaal aantal zoogbeurten, het aantal succesvolle zoogbeurten en het aantal niet succesvolle zoogbeurten is geregistreerd.

- Gewicht binnen 24 u na geboorte (zowel levend als dood geboren biggen), dag 27 (dag voor spenen van A4 biggen en dag voor start IS van IS9 biggen), dag 33, dag 63 (dag van opleg in vleesvarkensstal), dag 68, dag 98 (overschakeling van startvoer naar groeivoer), dag 126 (overschakeling van groeivoer naar eindvoer) en dag voor levering naar het slachthuis.

- Bij uitval van een dier zijn de datum, het gewicht en de reden van uitval vastgelegd.

- Bij veterinaire behandeling van een dier (dieren zijn zoveel mogelijk individueel behandeld) zijn de datum en de reden van behandeling en het gebruikte medicijn vastgelegd.

- Voeropname per voersoort op groepsniveau. De voertotalen per groep zijn bij elke weging van de dieren en bij uitval van een dier genoteerd. In de kraamstal konden de biggen mee eten met de zeugen van het zeugenvoer. Het is niet bekend hoeveel zeugenvoer ze opgenomen hebben.

- Huid-, staart- en oorbeschadigingen op dag 62 en dag 126 (protocol zie bijlage 1).

- Diarreescore: op dag 33, 40, 68 en 75 is per dier genoteerd of er normale mest, pasteuze mest of waterdunne mest op het achterwerk van de dieren aanwezig was.

- Frequentie van spelgedrag, oraal manipulatief gedrag, agressief gedrag, belly nosing (het wrijven van de buik van een ander varken via het op en neer bewegen van de snuit) en activiteit op dag 34, 41, 69, 76 en 127 (ethogram zie bijlage 2). Op dag 34 en 41 zijn de gedragswaarnemingen uitgevoerd bij vier (twee beren en twee zeugjes) van de zeven geselecteerde biggen per toom. Op dag 69, 76 en 127 zijn de gedragswaarnemingen uitgevoerd bij alle zeven geselecteerde biggen per toom. De gedragswaarmeningen zijn uitgevoerd gedurende 6 keer 10 minuten per dag tussen 8.00 en 16.00 u. Gedurende de 10 minuten werd continu waargenomen. De activiteit van de dieren werd gescoord aan het begin en aan het eind van elke 10 minuten waarnemen.

- Slachtgegevens: geslacht gewicht, vleespercentage, spier- en spekdikte.

\subsection{Gegevensverwerking en statistische analyse}

De gegevens zijn geanalyseerd met behulp van SAS 9.2 (SAS Inst. Inc., Cary, NC) en Genstat (2013). Per ronde per proefbehandeling zijn de resultaten gemiddeld, waarbij voor spenen een groep van 5 zeugen de experimentele eenheid was, na spenen een groep van maximaal 35 biggen en na opleg in de vleesvarkensstal een groep van maximaal 35 vleesvarkens.

Voeropname, gewicht en spekdikte van de zeugen, het aantal levend en dood geboren biggen, het aantal bij- en weggelegde biggen, het aantal gespeende biggen, de gewichten van de biggen en vleesvarkens, de groei, voeropname en voederconversie van de gespeende biggen en vleesvarkens, de gemiddelde score voor beschadigingen van de biggen en vleesvarkens en de slachtgegevens van de vleesvarkens zijn geanalyseerd met het volgende model: 
$Y=\mu+$ ronde + proefbehandeling (A4 groep vs IS9 groep) + rest

De gedragswaarnemingen en de gemiddelde diarreescore zijn geanalyseerd met het volgende model: $Y=\mu+$ ronde + proefbehandeling + dag van waarnemen + proefbehandeling $x$ dag van waarnemen + rest

Zoogfrequentie is geanalyseerd met een model waarin ronde en dag van waarnemen waren opgenomen.

Het aantal uitgevallen dieren, het aantal veterinair behandelde dieren en het percentage dieren met diarree zijn geanalyseerd met de chi-kwadraat toets.

18 | Wageningen Livestock Research Rapport 1012 


\section{Resultaten}

\subsection{Zeugen in kraamstal}

\subsubsection{Voerverbruik, gewicht en spekdikte}

Het voerverbruik van de zeugen in de kraamstal en het gewicht en de spekdikte van de zeugen bij inleg in de kraamstal en op dag 28 en 63 (alleen IS groep) na werpen zijn weergegeven in tabel 1.

Tabel 1 Voerverbruik, gewicht en spekdikte in de kraamstal van zeugen in een groepskraamsysteem; de biggen zijn abrupt gespeend op 4 weken leeftijd (A4) of geleidelijk op 9 weken leeftijd door toepassing van intermittent suckling (IS9) (verplichte IS gedurende 10 uur per dag van dag 28 t/m dag 34 na werpen; van dag 35 tot dag 63 na werpen konden de zeugen de biggen vrijwillig verlaten)

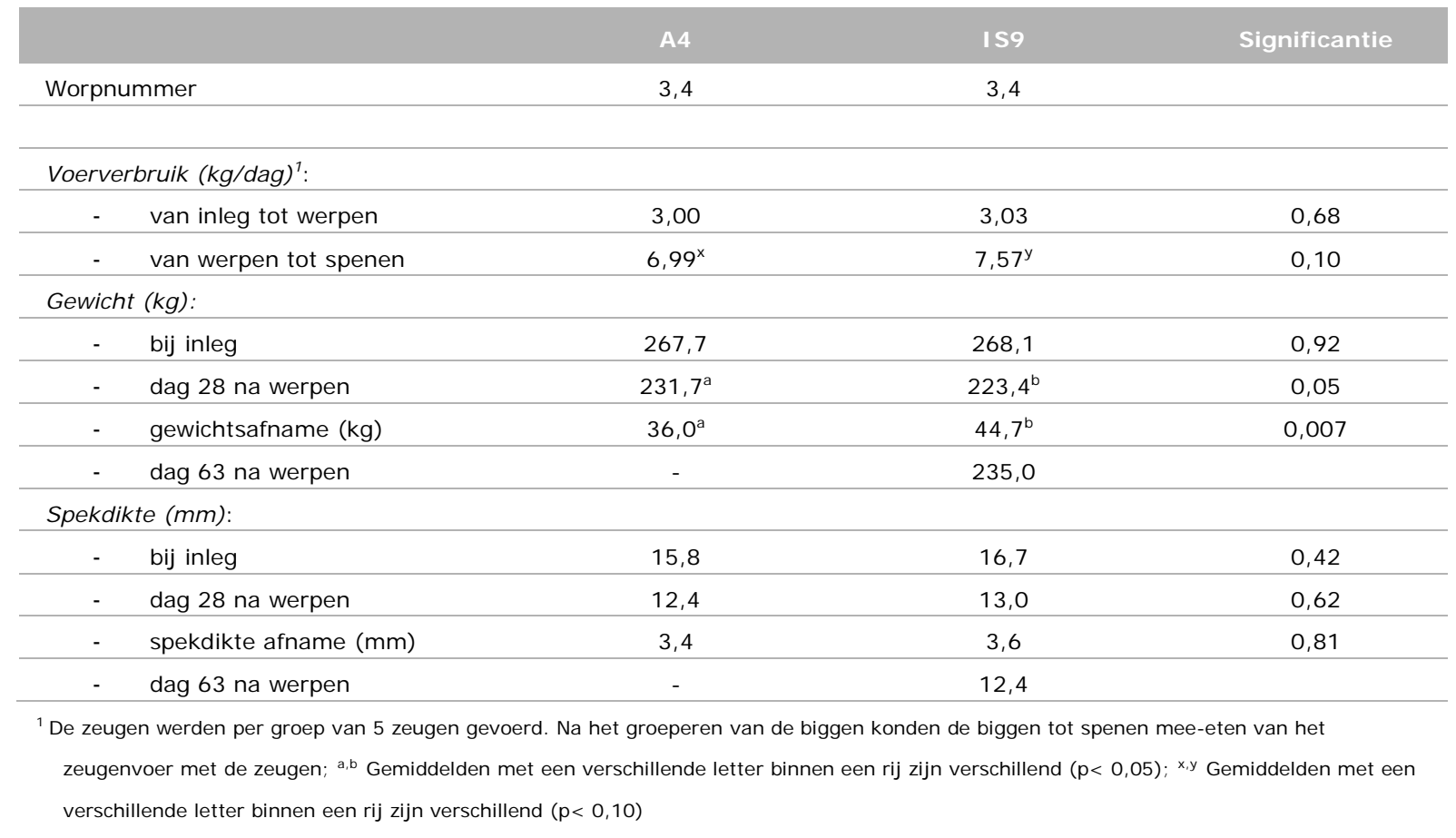

Uit tabel 1 blijkt dat er van inleg kraamstal tot werpen geen verschil was in voerverbruik tussen de A4 zeugen en de IS9 zeugen. Van werpen tot spenen (is 4 weken na werpen in de A4 groep en 9 weken na werpen in de IS9 groep) was er een tendens tot een hoger voerverbruik bij de IS9 zeugen. De biggen konden na groeperen tot spenen mee eten met de zeugen van het zeugenvoer. De zeugen in de IS9 groep verloren meer gewicht van inleg kraamstal tot dag 28 na werpen dan de zeugen uit de A4 groep. Van dag 28 tot dag 63 na werpen zijn de IS9 zeugen 11,6 kg in gewicht toegenomen en 0,6 $\mathrm{mm}$ in spek afgenomen.

\subsubsection{Aantal geboren biggen en uitval biggen tot 4 weken na werpen}

Het aantal levend en dood geboren biggen, het aantal uitgevallen en veterinair behandelde biggen, het aantal biggen op 4 weken na werpen en de gewichten van de biggen zijn weergegeven in tabel 2 . 
Tabel 2 Aantal geboren, uitgevallen en individueel veterinair behandelde biggen en aantal biggen op 4 weken na werpen bij zeugen in een groepskraamsysteem; de biggen zijn abrupt gespeend op 4 weken leeftijd (A4) of geleidelijk op 9 weken leeftijd door toepassing van intermittent suckling (IS9) (verplichte IS gedurende 10 uur per dag van dag 28 t/m dag 34 na werpen; van dag 35 tot dag 63 na werpen konden de zeugen de biggen vrijwillig verlaten)

\begin{tabular}{|c|c|c|c|}
\hline & A4 & IS9 & Significantie \\
\hline Aantal zeugen ${ }^{1}$ & 23 & 24 & \\
\hline Totaal geboren biggen & 16,1 & 16,2 & 0,87 \\
\hline Levend geboren biggen & 14,9 & 15,3 & 0,58 \\
\hline Doodgeboren biggen & 1,2 & 0,9 & 0,53 \\
\hline Bijgelegde biggen & 0,1 & 0,4 & 0,53 \\
\hline Beginaantal biggen & 15,0 & 15,7 & 0,14 \\
\hline Aantal uitgevallen biggen & 3,5 & 3,6 & 0,88 \\
\hline - $\quad$ Doodgelegen biggen & 2,2 & 1,9 & \\
\hline - $\quad$ Overige uitval & 1,3 & 1,7 & \\
\hline Aantal biggen op 4 weken na werpen & 11,5 & 12,1 & 0,26 \\
\hline Geboortegewicht beginaantal biggen $^{2}(\mathrm{~kg})$ & 1,39 & 1,37 & 0,41 \\
\hline Geboortegewicht biggen aanwezig 4 weken na werpen $(\mathrm{kg})$ & 1,44 & 1,42 & 0,44 \\
\hline Gewicht biggen 4 weken na werpen $(\mathrm{kg})$ & 7,2 & 7,2 & 0,96 \\
\hline Groei tot 4 weken na werpen $(g / d)$ & 215 & 218 & 0,80 \\
\hline Opname biggenvoer tot 4 weken na werpen (kg/big) & 0,17 & 0,13 & 0,40 \\
\hline Veterinair behandelde biggen ( $\%$ ) & 16,2 & 17,0 & 0,79 \\
\hline
\end{tabular}

${ }^{1}$ Drie zeugen zijn in de eerste week na werpen uitgevallen ( 2 zeugen gestorven en 1 zeug had geen melk); de gegevens van deze zeugen en bijbehorende biggen zijn niet meegenomen; ${ }^{2}$ Beginaantal = levend geboren - weggelegd + bijgelegd

Uit tabel 2 blijkt dat er van werpen tot 4 weken na werpen geen verschillen waren in aantal geboren, uitgevallen en individueel veterinair behandelde biggen tussen de A4 groep en de IS9 groep. Van de uitgevallen biggen is ca. $60 \%$ doodgelegen in de eerste dagen na werpen en is $40 \%$ uitgevallen vanwege laag geboortegewicht, spreidzit en diverse redenen. In de A4 groep zijn 3,0 biggen uitgevallen in de eerste week na werpen (in het werphok) en 0,5 big na groeperen van de tomen. In de IS9 groep zijn 3,1 biggen uitgevallen in de eerste week na werpen (in het werphok) en 0,5 big na groeperen van de tomen.

Er was geen verschil in groei van de biggen en in de opname van biggenvoer. In ronde 1 zijn alle biggen in de derde week na geboorte gedurende 2 dagen via een injectie behandeld vanwege problemen met kreupelheden.

\subsubsection{Inseminatie tijdens lactatiebronst en resultaten volgende worp}

In tabel 3 is het aantal zeugen weergegeven dat geïnsemineerd is binnen een week na spenen (A4 groep) of binnen een week na start IS (IS9 groep). Daarnaast is het aantal zeugen weergegeven dat geworpen heeft van $1^{\text {ste }}$ inseminatie en het aantal levend en dood geboren biggen in de volgende worp. 
Tabel 3 Aantal geïnsemineerde zeugen tussen dag 28 en 35 na werpen van zeugen in een groepskraamsysteem; de biggen zijn abrupt gespeend op 4 weken leeftijd (A4) of geleidelijk op 9 weken leeftijd door toepassing van intermittent suckling (IS9) (verplichte IS gedurende 10 uur per dag van dag 28 t/m dag 34 na werpen; van dag 35 tot dag 63 na werpen konden de zeugen de biggen vrijwillig verlaten)

\begin{tabular}{|c|c|c|}
\hline & A4 & IS9 \\
\hline Aantal zeugen op dag 28 na werpen & 23 & 24 \\
\hline Aantal zeugen geïnsemineerd tussen dag 28 en 35 na werpen ${ }^{1}$ & 23 & 19 \\
\hline Aantal afgebigd van $1^{\text {ste }}$ inseminatie ${ }^{2}$ & 21 & 17 \\
\hline Totaal geboren biggen volgende worp & 17,4 & 17,7 \\
\hline Levend geboren biggen volgende worp & 15,6 & 16,5 \\
\hline Doodgeboren biggen volgende worp & 1,8 & 1,2 \\
\hline
\end{tabular}

1 In ronde 1 is één zeug van de vijf zeugen binnen een week na de start van IS berig geworden, in ronde 2 vier van de vijf zeugen en in ronde 3 t/m 5 alle 14 zeugen; ${ }^{2}$ In de A4 groep is één zeug opnieuw geïnsemineerd en is één zeug afgevoerd vanwege onregelmatige terugkomer; In de IS9 groep is één zeug teruggekomen en afgevoerd en is één zeug gestorven (reden onbekend) in de drachtstal.

Uit tabel 3 blijkt dat het afbigpercentage van $1^{\text {ste }}$ inseminatie in de A4 groep 91,3\% was en in de IS9 groep 89,5\%. In de IS9 groep werd in ronde 1 slechts 1 van de 5 zeugen berig tijdens de verplichte IS (de overige 4 zeugen werden berig na spenen op 9 weken na werpen). In ronde 1 was de beer tijdens de verplichte IS continue in de IS- ruimte aanwezig. In ronde $2 \mathrm{t} / \mathrm{m} 5$ was de was de beer alleen tijdens de eerste twee dagen van de verplichte IS continue in de IS-ruimte aanwezig. De overige dagen was de beer slechts een paar uur per dag in de IS-ruimte aanwezig. In ronde 2 t/m 5 zijn 18 van de 19 zeugen berig geworden tijdens de verplichte IS ( 1 zeug is berig geworden op dag 17 na de start van de verplichte IS).

\subsection{Technische resultaten biggen en vleesvarkens}

\subsubsection{Zoogfrequentie IS9 biggen}

In figuur 2 is de zoogfrequentie van de IS9 biggen weergegeven. Het totaal aantal zoogbeurten en het aantal succesvolle (met melkafgifte) en niet succesvolle (geen melkafgifte) zoogbeurten is weergegeven.

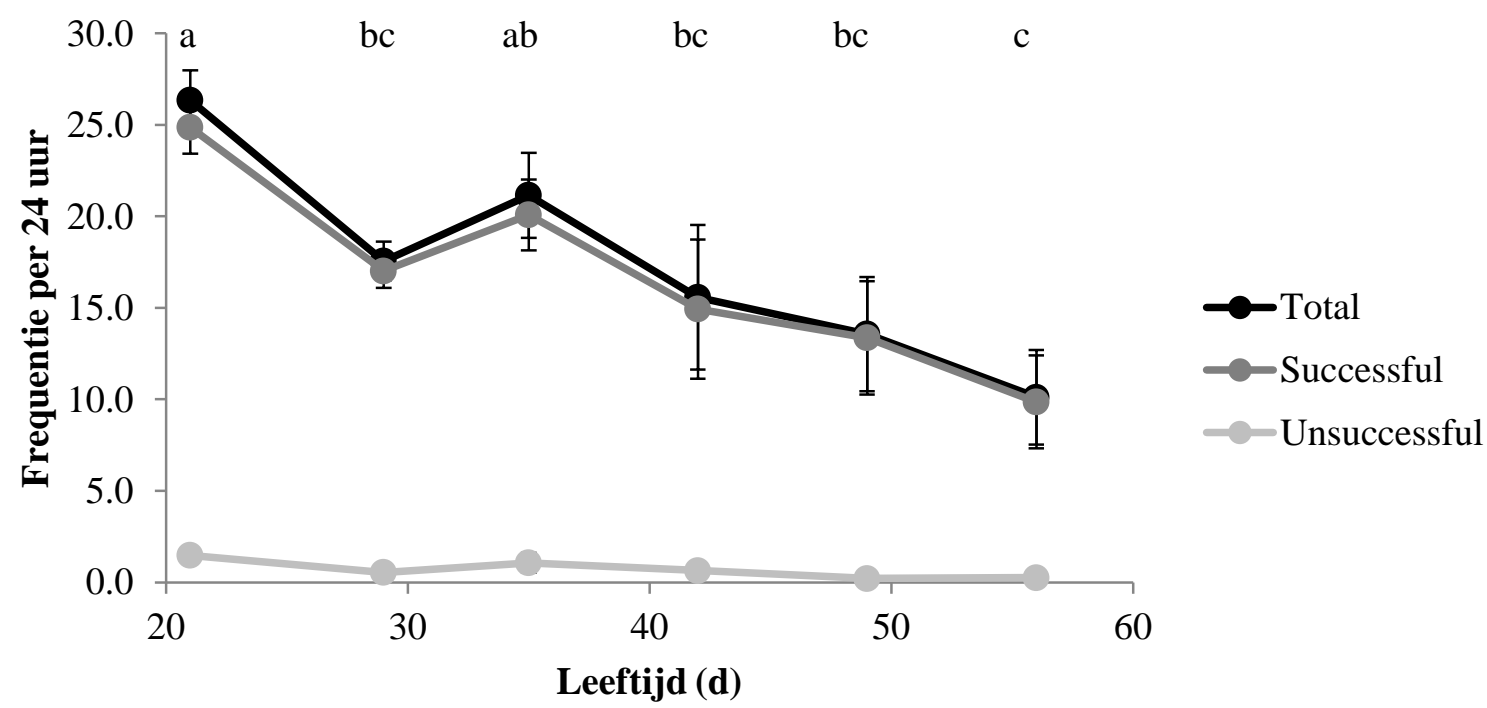

Figuur 2 Zoogfrequentie van biggen opgegroeid in een groepskraamsysteem; de biggen zijn geleidelijk gespeend op 9 weken leeftijd door toepassing van intermittent suckling (IS9) (van dag 28 t/m dag 34 na werpen werden de zeugen en biggen 10 uur per dag van elkaar gescheiden; van dag 35 tot dag 63 na werpen konden de zeugen de biggen vrijwillig verlaten); ${ }^{a, b, c}$ Dagen met een verschillende letter verschillen significant van elkaar $(p<0,01)$ 
Uit figuur 2 blijkt dat de zoogfrequentie op dag 29 (de $2^{\text {de }}$ dag van verplichte IS) lager was dan op dag 21 (voor de start van IS) (17,6 vs 26,4 zoogbeurten per 24 uur). Van dag 35 tot dag 56 na werpen daalde de zoogfrequentie van 21,2 naar 10,1 zoogbeurten per 24 uur. Het cumulatieve percentage zeugen met niet succesvolle zoogbeurten was $0 \%$ op dag 35, 8,3\% op dag $42,12,5 \%$ op dag 49 en $20,8 \%$ op dag 56 .

\subsubsection{Technische resultaten biggen 4 tot 9 weken leeftijd}

De technische resultaten van de biggen van 4 tot 9 weken leeftijd zijn weergegeven in tabel 4 .

Tabel 4 Technische resultaten van 4 tot 9 weken leeftijd van biggen opgegroeid in een groepskraamsysteem; de biggen zijn abrupt gespeend op 4 weken leeftijd en daarna tot 9 weken leeftijd gehuisvest in een verrijkt hok in een groep van 35 biggen (A4) of geleidelijk gespeend op 9 weken leeftijd door toepassing van intermittent suckling (IS9) (van dag $28 \mathrm{t} / \mathrm{m}$ dag 34 na werpen werden de zeugen en biggen 10 uur per dag van elkaar gescheiden; van dag 35 tot dag 63 na werpen konden de zeugen de biggen vrijwillig verlaten)

\begin{tabular}{|c|c|c|c|}
\hline & A4 & IS9 & Significantie \\
\hline Aantal dieren & 172 & 290 & \\
\hline Aantal hokken & 5 & 5 & \\
\hline \multicolumn{4}{|l|}{ Dag 28 tot dag 33: } \\
\hline Gewicht dag $28(\mathrm{~kg})$ & 7,2 & 7,3 & 0,76 \\
\hline Groei (g/d) & $179^{a}$ & $305^{\mathrm{b}}$ & 0,007 \\
\hline Opname biggenvoer $\mathrm{kg} / \mathrm{d})^{1}$ & $0,25^{\mathrm{a}}$ & $0,06^{\mathrm{b}}$ & 0,01 \\
\hline \multicolumn{4}{|l|}{ Dag 33 tot dag 63: } \\
\hline Gewicht dag $33(\mathrm{~kg})$ & $8,1^{x}$ & $8,9^{y}$ & 0,08 \\
\hline Groei (g/d) & 479 & 519 & 0,25 \\
\hline Opname biggenvoer $(\mathrm{kg} / \mathrm{d})^{1}$ & $0,74^{\mathrm{a}}$ & $0,38^{\mathrm{b}}$ & 0,005 \\
\hline \multicolumn{4}{|l|}{ Dag 28 tot dag 63: } \\
\hline Gewicht dag $63(\mathrm{~kg})$ & 22,5 & 24,4 & 0,16 \\
\hline Groei $(\mathrm{g} / \mathrm{d})$ & 436 & 488 & 0,12 \\
\hline Opname biggenvoer $(\mathrm{kg} / \mathrm{d})^{1}$ & $0,67^{\mathrm{a}}$ & $0,33^{b}$ & 0,004 \\
\hline \multicolumn{4}{|c|}{$\begin{array}{l}{ }^{1} \text { de opname van melk bij de zeug en de opname van zeugenvoer is niet bekend bij de IS9 biggen; }{ }^{a, b} \text { Gemiddelden met een verschillende letter } \\
\text { binnen een rij zijn verschillend }(p<0,05) \text {; }{ }^{x, y} \text { Gemiddelden met een verschillende letter binnen een rij tenderen naar verschillend }(p<0,10)\end{array}$} \\
\hline \multicolumn{4}{|c|}{$\begin{array}{l}\text { Uit tabel } 4 \text { blijkt dat de IS9 biggen van dag } 28 \text { tot dag } 33 \text { significant sneller zijn gegroeid dan de A4 } \\
\text { biggen. Van dag } 33 \text { tot dag } 63 \text { en van dag } 28 \text { tot dag } 63 \text { zijn de IS9 biggen respectievelijk } 40 \text { en } 50 \\
\text { g/d sneller gegroeid dan de A4 biggen. Deze verschillen in groei waren echter niet significant. De IS9 } \\
\text { biggen hebben van dag } 28 \text { tot dag } 33 \text { en van dag } 33 \text { tot dag } 63 \text { minder biggenvoer opgenomen dan de } \\
\text { A4 biggen. De opname van melk en van zeugenvoer door de IS9 biggen is niet bekend. }\end{array}$} \\
\hline
\end{tabular}

\subsubsection{Uitval en veterinaire behandelingen biggen 4 tot 9 weken leeftijd}

Het percentage uitgevallen en individueel veterinair behandelde biggen van 4 tot 9 weken leeftijd is weergegeven in tabel 5 . 
Tabel 5 Percentage uitgevallen en individueel veterinair behandelde biggen opgegroeid in een groepskraamsysteem; de biggen zijn abrupt gespeend op 4 weken leeftijd en daarna tot 9 weken leeftijd gehuisvest in een verrijkt hok in een groep van 35 biggen (A4) of geleidelijk gespeend op 9 weken leeftijd door toepassing van intermittent suckling (IS9) (van dag $28 \mathrm{t} / \mathrm{m}$ dag 34 na werpen werden de zeugen en biggen 10 uur per dag van elkaar gescheiden; van dag 35 tot dag 63 na werpen konden de zeugen de biggen vrijwillig verlaten)

\begin{tabular}{|c|c|c|c|}
\hline & A4 & Is9 & Significantie \\
\hline Aantal biggen & 172 & 290 & \\
\hline Aantal uitgevallen & $6(3,5 \%)$ & $9(3,1 \%)$ & 0,82 \\
\hline \multicolumn{4}{|l|}{ Per reden van uitval: } \\
\hline - beenwerkaandoeningen & 0 & 2 & 1 \\
\hline - Streptococcus suis infectie & 2 & 0 & 1 \\
\hline - doodliggen & 0 & 2 & 1 \\
\hline - achterblijven in groei & 0 & 1 & 1 \\
\hline - diversen & 4 & 4 & 1 \\
\hline Aantal veterinair behandeld & $11(6,4 \%)$ & $30(10,3 \%)$ & 0,15 \\
\hline \multicolumn{4}{|l|}{ Per reden van behandelen: } \\
\hline - beenwerkaandoeningen & 7 & 22 & 0,13 \\
\hline - Streptococcus suis infectie & 2 & 7 & 0,35 \\
\hline - diversen & 2 & 1 & 1 \\
\hline
\end{tabular}

Uit tabel 5 blijkt dat er van 4 tot 9 weken leeftijd geen verschil was in percentage uitgevallen en individueel veterinair behandelde biggen tussen de A4 en de IS9 biggen. De meeste biggen zijn behandeld vanwege beenwerkaandoeningen.

\subsubsection{Technische resultaten en slachtkwaliteit vleesvarkens}

In tabel 6 zijn de technische resultaten tijdens de vleesvarkensfase weergegeven.

Tabel 6 Technische resultaten tijdens de vleesvarkensfase van vleesvarkens opgegroeid in een groepskraamsysteem en abrupt gespeend op 4 weken leeftijd en daarna tot 9 weken leeftijd gehuisvest in een verrijkt hok in een groep van 35 biggen (A4) of geleidelijk gespeend op 9 weken leeftijd door toepassing van intermittent suckling (IS9); op een leeftijd van 9 weken zijn zowel de A4 als de IS9 biggen opgelegd in verrijkte vleesvarkenshokken voor 35 dieren.

\begin{tabular}{|c|c|c|c|}
\hline & A4 & 159 & Significantie \\
\hline Aantal dieren & 166 & 165 & \\
\hline Aantal hokken & 5 & 5 & \\
\hline Opleggewicht (kg) & $22,5^{x}$ & $25,2^{y}$ & 0,08 \\
\hline Levend eindgewicht $(\mathrm{kg})$ & $120,5^{x}$ & $121,7^{y}$ & 0,07 \\
\hline Aantal dagen & 108,0 & 105,8 & \\
\hline Groei (kg/d) & 910 & 915 & 0,83 \\
\hline Voeropname $(\mathrm{kg} / \mathrm{d})$ & 2,33 & 2,34 & 0,88 \\
\hline Voederconversie & 2,56 & 2,56 & 0,93 \\
\hline
\end{tabular}

$x, y$ Gemiddelden met een verschillende letter binnen een rij tenderen naar verschillend $(p<0,10)$

Uit tabel 6 blijkt dat er geen verschillen zijn in groei, voeropname en voederconversie tussen de A4 en IS9 vleesvarkens. De IS 9 vleesvarkens waren zwaarder bij opleg in de vleesvarkensstal en zwaarder bij afleveren.

In tabel 7 zijn de technische resultaten tijdens de vleesvarkensfase weergegeven per deeltraject. 
Tabel 7 Technische resultaten per deeltraject tijdens de vleesvarkensfase van vleesvarkens opgegroeid in een groepskraamsysteem en abrupt gespeend op 4 weken leeftijd en daarna tot 9 weken leeftijd gehuisvest in een verrijkt hok in een groep van 35 biggen (A4) of geleidelijk gespeend op 9 weken leeftijd door toepassing van intermittent suckling (IS9); op een leeftijd van 9 weken zijn zowel de A4 als de IS9 biggen opgelegd in verrijkte vleesvarkenshokken voor 35 dieren.

\begin{tabular}{|c|c|c|c|}
\hline & $\mathbf{A 4}$ & 159 & Significantie \\
\hline Aantal dieren & 166 & 165 & \\
\hline Aantal hokken & 5 & 5 & \\
\hline \multicolumn{4}{|l|}{ Van opleg tot 5 dagen na opleg: } \\
\hline Opleggewicht (kg) & $22,5^{x}$ & $25,2^{y}$ & 0,08 \\
\hline Groei $(\mathrm{kg} / \mathrm{d})$ & 628 & 648 & 0,77 \\
\hline Voeropname $(\mathrm{kg} / \mathrm{d})$ & 1,46 & 1,46 & 0,90 \\
\hline Voederconversie & 2,38 & 2,27 & 0,54 \\
\hline \multicolumn{4}{|c|}{ Van 5 dagen na opleg tot 5 weken na opleg (startvoerfase): } \\
\hline Gewicht dag 5 na opleg $(\mathrm{kg})$ & 25,6 & 28,4 & 0,12 \\
\hline Groei $(\mathrm{kg} / \mathrm{d})$ & 784 & 871 & 0,23 \\
\hline Voeropname $(\mathrm{kg} / \mathrm{d})$ & 1,63 & 1,70 & 0,40 \\
\hline Voederconversie & 2,11 & 1,95 & 0,35 \\
\hline \multicolumn{4}{|c|}{ Van 5 weken na opleg tot 9 weken na opleg (groeivoerfase): } \\
\hline Gewicht dag 35 na opleg $(\mathrm{kg})$ & $49,2^{\mathrm{a}}$ & $54,5^{\mathrm{b}}$ & 0,04 \\
\hline Groei $(\mathrm{kg} / \mathrm{d})$ & 1012 & 926 & 0,14 \\
\hline Voeropname $(\mathrm{kg} / \mathrm{d})$ & 2,39 & 2,44 & 0,49 \\
\hline Voederconversie & $2,36^{\mathrm{x}}$ & $2,66^{y}$ & 0,08 \\
\hline \multicolumn{4}{|c|}{ Van 9 weken na opleg tot $1^{\mathrm{e}}$ levering (eindvoerfase): } \\
\hline Gewicht dag 63 na opleg $(\mathrm{kg})$ & $77,5^{x}$ & $80,5^{y}$ & 0,07 \\
\hline Gewicht $1^{\mathrm{e}}$ levering $(\mathrm{kg})$ & 111,3 & 114,4 & 0,18 \\
\hline Aantal dagen & 34,3 & 34,3 & \\
\hline Groei $(\mathrm{kg} / \mathrm{d})$ & 984 & 996 & 0,69 \\
\hline Voeropname $(\mathrm{kg} / \mathrm{d})$ & 2,81 & 2,81 & 0,98 \\
\hline Voederconversie & 2,85 & 2,83 & 0,84 \\
\hline \multicolumn{4}{|c|}{ Van 9 weken na opleg tot laatste levering: } \\
\hline Levend eindgewicht $(\mathrm{kg})$ & $120,5^{x}$ & $121,7^{y}$ & 0,07 \\
\hline Aantal dagen & 44,9 & 42,9 & \\
\hline Groei $(\mathrm{kg} / \mathrm{d})$ & 953 & 963 & 0,64 \\
\hline Voeropname $(\mathrm{kg} / \mathrm{d})$ & 2,84 & 2,80 & 0,44 \\
\hline Voederconversie & 2,98 & 2,92 & 0,30 \\
\hline
\end{tabular}

Uit tabel 7 blijkt dat er geen verschillen zijn in technische resultaten tussen de A4 en IS9 vleesvarkens in de verschillende deeltrajecten. De IS 9 vleesvarkens waren op alle weegmomenten zwaarder dan de A4 vleesvarkens.

In tabel 8 is de slachtkwaliteit van de vleesvarkens weergegeven. 
Tabel 8 Slachtkwaliteit van vleesvarkens opgegroeid in een groepskraamsysteem en abrupt gespeend op 4 weken leeftijd en daarna tot 9 weken leeftijd gehuisvest in een verrijkt hok in een groep van 35 biggen (A4) of geleidelijk gespeend op 9 weken leeftijd door toepassing van intermittent suckling (IS9); op een leeftijd van 9 weken zijn zowel de A4 als de IS9 biggen opgelegd in verrijkte vleesvarkenshokken voor 35 dieren.

\begin{tabular}{llll} 
& A4 & Is9 & Significantie \\
Aantal dieren & 155 & 160 & 0,63 \\
\hline Slachtgewicht $(\mathrm{kg})$ & 93,5 & 93,8 & 0,62 \\
\hline Vleespercentage & 58,8 & 58,9 & 0,41 \\
\hline Spierdikte $(\mathrm{mm})$ & 64,0 & 64,8 & 0,68 \\
\hline Spekdikte $(\mathrm{mm})$ & 14,3 & 14,2 & 0,30 \\
\hline Aanhoudingspercentage & 77,4 & 77,1 & 0
\end{tabular}

a,b Gemiddelden met een verschillende letter binnen een rij zijn verschillend $(p<0,05)$

Uit tabel 8 blijkt dat er geen verschillen zijn in slachtkwaliteit tussen de A4 en IS9 vleesvarkens.

\subsubsection{Uitval en veterinaire behandelingen vleesvarkens}

Het aantal uitgevallen en individueel veterinair behandelde vleesvarkens is weergegeven in tabel 9.

Tabel 9 Uitval en veterinaire behandelingen bij vleesvarkens opgegroeid in een groepskraamsysteem en abrupt gespeend op 4 weken leeftijd en daarna tot 9 weken leeftijd gehuisvest in een verrijkt hok in een groep van 35 biggen (A4) of geleidelijk gespeend op 9 weken leeftijd door toepassing van intermittent suckling (IS9); op een leeftijd van 9 weken zijn zowel de A4 als de IS9 biggen opgelegd in verrijkte vleesvarkenshokken voor 35 dieren.

\begin{tabular}{|c|c|c|c|}
\hline & A4 & IS9 & Significantie \\
\hline Aantal dieren opgelegd & 166 & 165 & \\
\hline Aantal uitgevallen & $11(6,6 \%)$ & $5(3,0 \%)$ & 0,13 \\
\hline \multicolumn{4}{|l|}{ Per reden van uitval: } \\
\hline - $\quad$ beenwerkaandoeningen & 1 & 0 & 2 \\
\hline - $\quad$ luchtwegaandoeningen & 2 & 0 & 2 \\
\hline - $\quad$ Streptococcus suis infectie & 2 & 2 & 2 \\
\hline - $\quad$ achterblijven in groei & 3 & 2 & 2 \\
\hline - $\quad$ onbekend & 3 & 1 & 2 \\
\hline Aantal veterinair behandeld ${ }^{1}$ & $13(13,0 \%)$ & $12(12,1 \%)$ & 0,85 \\
\hline \multicolumn{4}{|l|}{ Per reden van behandelen: } \\
\hline - $\quad$ beenwerkaandoeningen & 4 & 3 & 2 \\
\hline - $\quad$ luchtwegaandoeningen & 5 & 5 & 2 \\
\hline - $\quad$ diversen & 4 & 4 & 2 \\
\hline
\end{tabular}

${ }^{1}$ Alleen gegevens van ronde 3, 4 en 5; de veterinaire behandelingen in ronde 1 en 2 zijn kwijt geraakt; ${ }^{2}$ Aantallen te laag om te toetsen;

Uit tabel 9 blijkt dat er in de A4 groep meer dieren zijn uitgevallen dan in de IS9 groep. Dit verschil is niet significant $(p=0,13)$. Er waren geen verschillen in het aantal individueel veterinair behandelde vleesvarkens. In ronde 3 zijn alle dieren gedurende twee dagen behandeld vanwege luchtwegaandoeningen via een middel door het voer. 


\subsection{Huid-, staart- en oorbeschadigingen en diarreescore bij biggen en vleesvarkens}

In tabel 10 zijn de huid-, staart- en oorbeschadigingen op dag 62 (dag voor opleg vleesvarkensstal) en dag 126 (dag van overschakeling van groeivoer naar eindvoer) weergegeven.

Tabel 10 Oor-, staart- en huidbeschadigingen op dag 62 en dag 126 bij biggen en vleesvarkens opgegroeid in een groepskraamsysteem en abrupt gespeend op 4 weken leeftijd en daarna tot 9 weken leeftijd gehuisvest in een verrijkt hok in een groep van 35 biggen (A4) of geleidelijk gespeend op 9 weken leeftijd door toepassing van intermittent suckling (IS9); op een leeftijd van 9 weken zijn zowel de A4 als de IS9 biggen opgelegd in verrijkte vleesvarkenshokken voor 35 dieren.

\begin{tabular}{|c|c|c|c|c|}
\hline & \multicolumn{2}{|c|}{ Dag 62} & \multicolumn{2}{|c|}{ Dag 126} \\
\hline & A4 & IS9 & A4 & IS9 \\
\hline Score oorbeschadigingen (score $0-4$ ) & 1,45 & 1,22 & $1,08^{\mathrm{a}}$ & $0,85^{b}$ \\
\hline Score staartbeschadigingen (score $0-3$ ) & $0,81^{x}$ & $0,62^{y}$ & 0,79 & 0,80 \\
\hline Totaal aantal krassen & 22,2 & 22,4 & $20,1^{x}$ & $16,4^{y}$ \\
\hline - Aantal oppervlakkige krassen & 21,0 & 20,0 & $17,7^{x}$ & $14,7^{\mathrm{y}}$ \\
\hline - Aantal diepe krassen & 1,2 & 2,3 & 2,4 & 1,7 \\
\hline - Krassen voorhand & 10,1 & 10,8 & $9,6^{x}$ & $7,6^{y}$ \\
\hline - Krassen middenhand & 9,0 & 8,0 & $6,4^{x}$ & $5,4^{y}$ \\
\hline - Krassen achterhand & 3,2 & 3,6 & 4,1 & 3,3 \\
\hline
\end{tabular}

Uit tabel 10 blijkt dat er op dag 62 een tendens was tot een lagere staartbeschadigingsscore bij de IS9 biggen dan bij de A4 biggen. Er waren op dag 62 geen verschillen in de oorbeschadigingsscore en in het aantal krassen tussen de A4 en IS9 biggen.

Op dag 126 was de oorbeschadigingsscore lager bij de IS9 vleesvarkens dan bij de A4 vleesvarkens. Daarnaast was er een tendens tot minder krassen, m.n. oppervlakkige krassen, bij de IS9 vleesvarkens. Op dag 126 was er geen verschil in staartbeschadigingsscore tussen de A4 en IS9 vleesvarkens.

Het percentage biggen en vleesvarkens met normale, pasteuze en waterdunne mest op dag 33, 40, 68 en 75 is weergegeven in figuur 3.

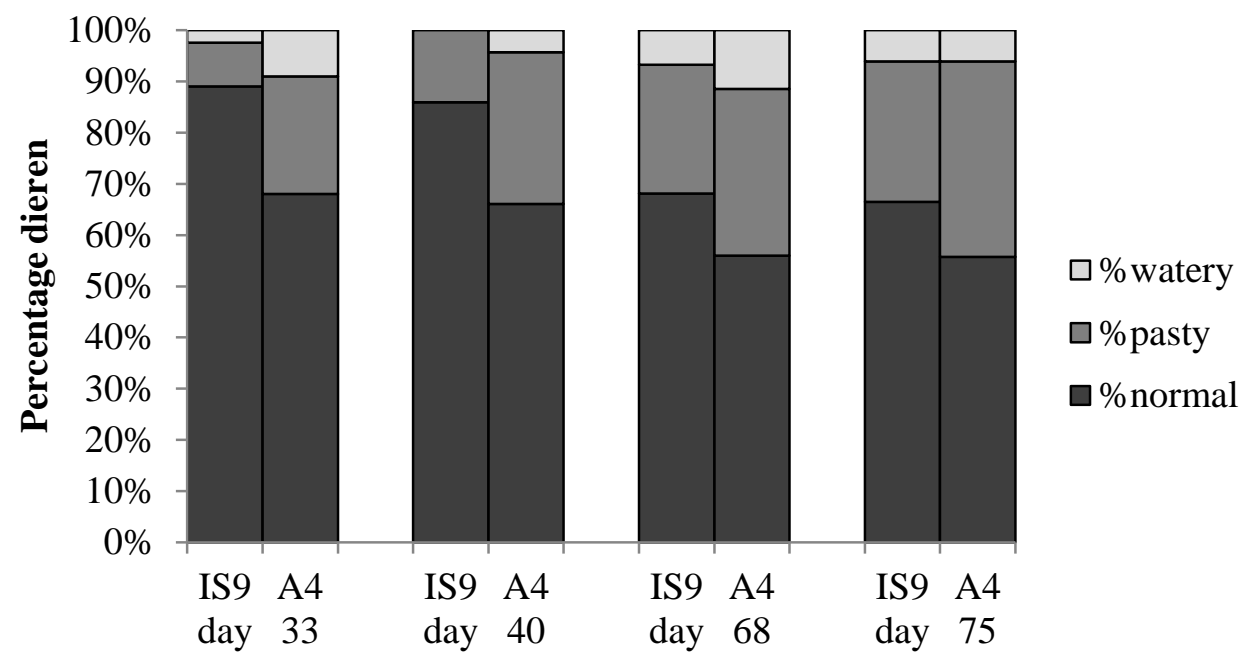

Figuur 3 Diarreescores op dag 33, 40, 68 en 75 bij biggen en vleesvarkens opgegroeid in een groepskraamsysteem en abrupt gespeend op 4 weken leeftijd en daarna tot 9 weken leeftijd gehuisvest in een verrijkt hok in een groep van 35 biggen (A4) of geleidelijk gespeend op 9 weken leeftijd door toepassing van intermittent suckling (IS9); op een leeftijd van 9 weken zijn zowel de A4 als de IS9 biggen opgelegd in verrijkte vleesvarkenshokken voor 35 dieren. 
Uit figuur 3 blijkt dat het percentage biggen en vleesvarkens met minstens één dag diarree niet verschilde tussen de A4 en IS9 dieren ( 80,5 en $59,7 \% ; p=0,51)$. Het aantal dagen dat de biggen en vleesvarkens diarree hadden was echter lager bij de IS9 varkens dan bij de A4 varkens (0,91 vs 1,54 dagen; $p<0,01$ ). De gemiddelde diarreescore was lager (d.w.z. meer normale mest) bij de IS9 varkens dan bij de $A 4$ varkens $(0,28$ vs 0,$45 ; p<0.05)$. De gemiddelde diarree score was lager op dag 33 en 40 dan op dag 68 en 75.

\subsection{Gedrag en activiteit biggen en vleesvarkens}

In figuur 4 is de frequentie van spelgedrag op dag 34, 41, 69, 76 en 127 weergegeven.

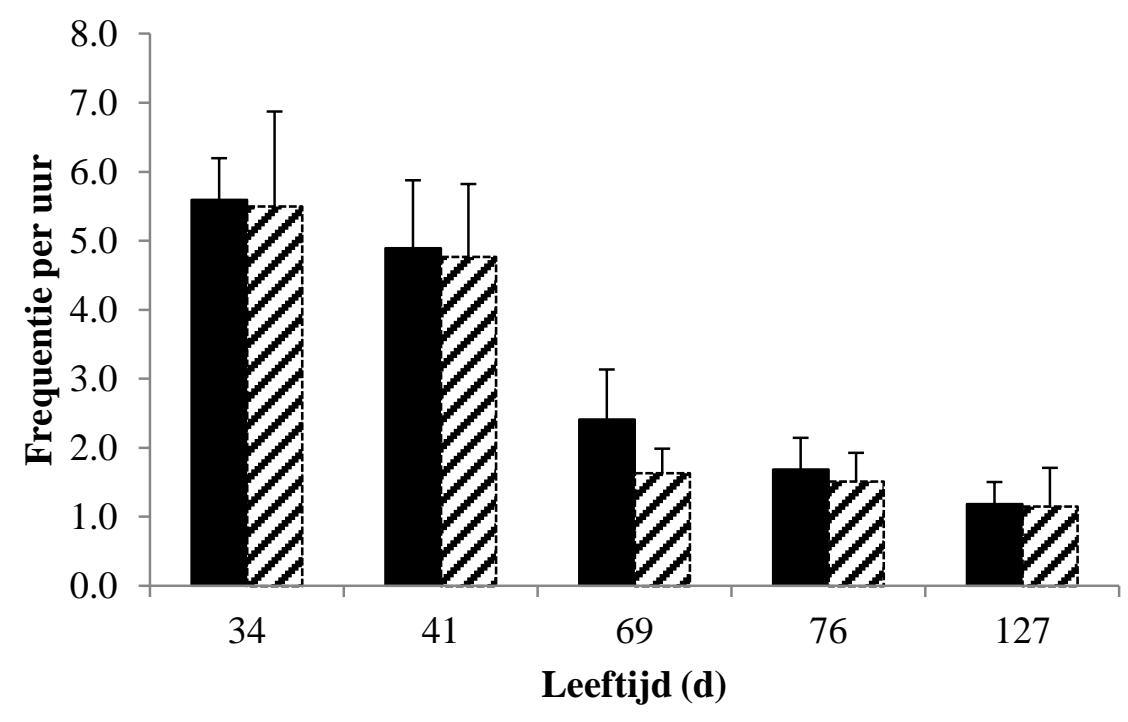

Figuur 4 Frequentie van spelgedrag op dag 34, 41, 69, 76 en 127 bij biggen en vleesvarkens opgegroeid in een groepskraamsysteem en abrupt gespeend op 4 weken leeftijd en daarna tot 9 weken leeftijd gehuisvest in een verrijkt hok in een groep van 35 biggen (A4; gestreepte balk) of geleidelijk gespeend op 9 weken leeftijd door toepassing van intermittent suckling (IS9; zwarte balk); op een leeftijd van 9 weken zijn zowel de A4 als de IS9 biggen opgelegd in verrijkte vleesvarkenshokken voor 35 dieren.

Uit figuur 4 blijkt dat er geen verschil was in spelgedrag tussen de A4 en IS9 varkens. Het spelgedrag nam af met het ouder worden van de dieren $(p<0,001)$. De dieren vertoonden meer spelgedrag op dag 34 en 41 dan op dag 69, 76 en 127.

In figuur 5 is de frequentie van oraal manipulatief gedrag op dag 34, 41, 69, 76 en 127 weergegeven. 

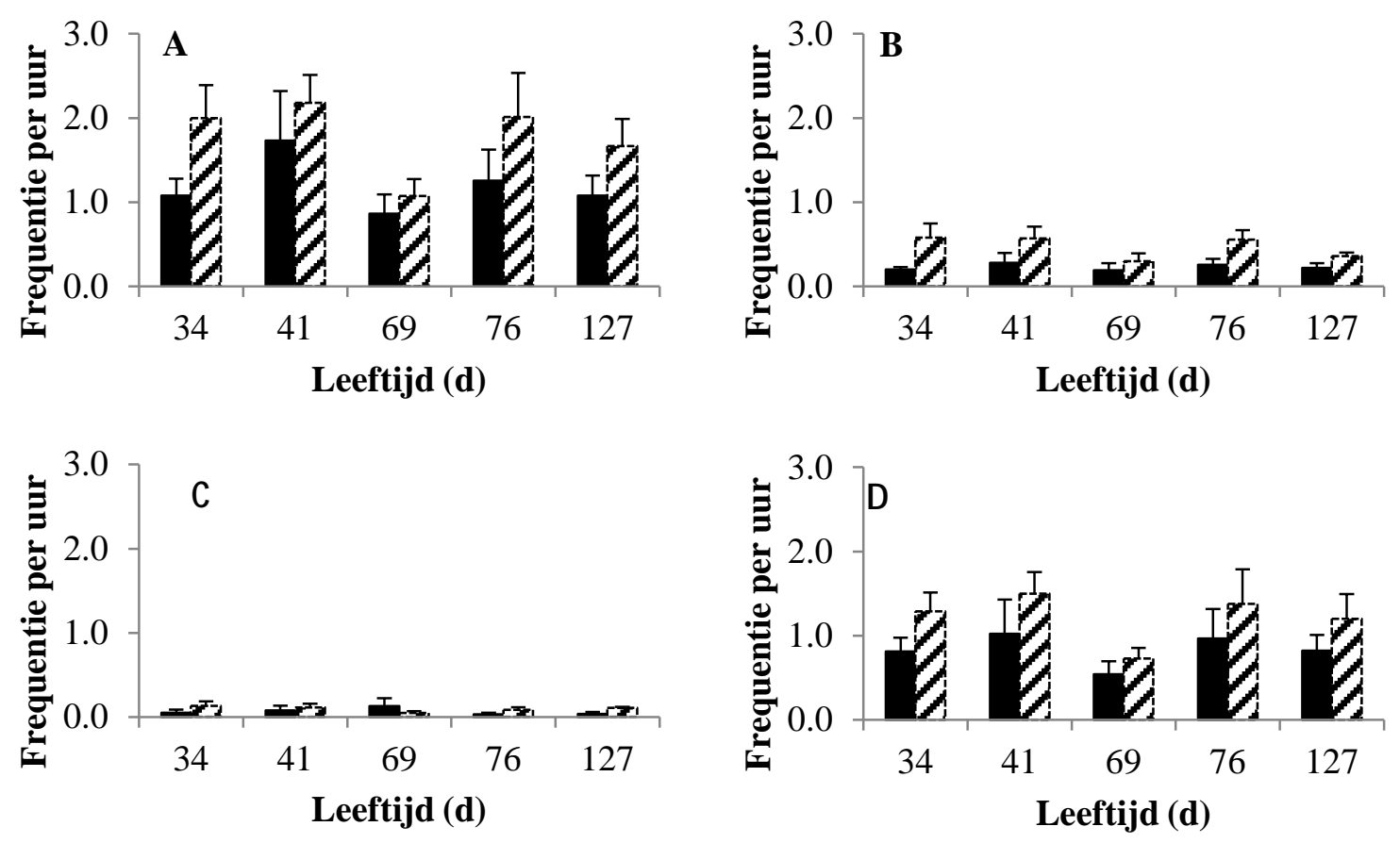

Figuur 5 Frequentie van totaal oraal manipulatief gedrag (A), oor manipulatie (B), staart manipulatie (C) en overig manipulatief gedrag (D) op dag 34, 41, 69, 76 en 127 bij biggen en vleesvarkens opgegroeid in een groepskraamsysteem en abrupt gespeend op 4 weken leeftijd en daarna tot 9 weken leeftijd gehuisvest in een verrijkt hok in een groep van 35 biggen (A4; gestreepte balk) of geleidelijk gespeend op 9 weken leeftijd door toepassing van intermittent suckling (IS9; zwarte balk); op een leeftijd van 9 weken zijn zowel de A4 als de IS9 biggen opgelegd in verrijkte vleesvarkenshokken voor 35 dieren; oraal manipulatief gedrag bestaat uit kauwen op een lichaamsdeel van een andere dier zoals kauwen op oren, staarten en andere lichaamsdelen.

Uit figuur 5 blijkt dat de IS9 dieren minder totaal oraal manipulatief gedrag vertoonden dan de A4 biggen $(p<0,05)$. Dit is m.n. het gevolg van minder oor manipulatie en overig manipulatief gedrag. Er was geen verschil in staart manipulatie tussen de A4 en IS9 dieren. Op dag 69 was het totaal oraal manipulatief gedrag lager dan op de andere meetdagen $(p<0,05)$.

In figuur 6 is de frequentie van agressief gedrag op dag 34, 41, 69, 76 en 127 weergegeven.
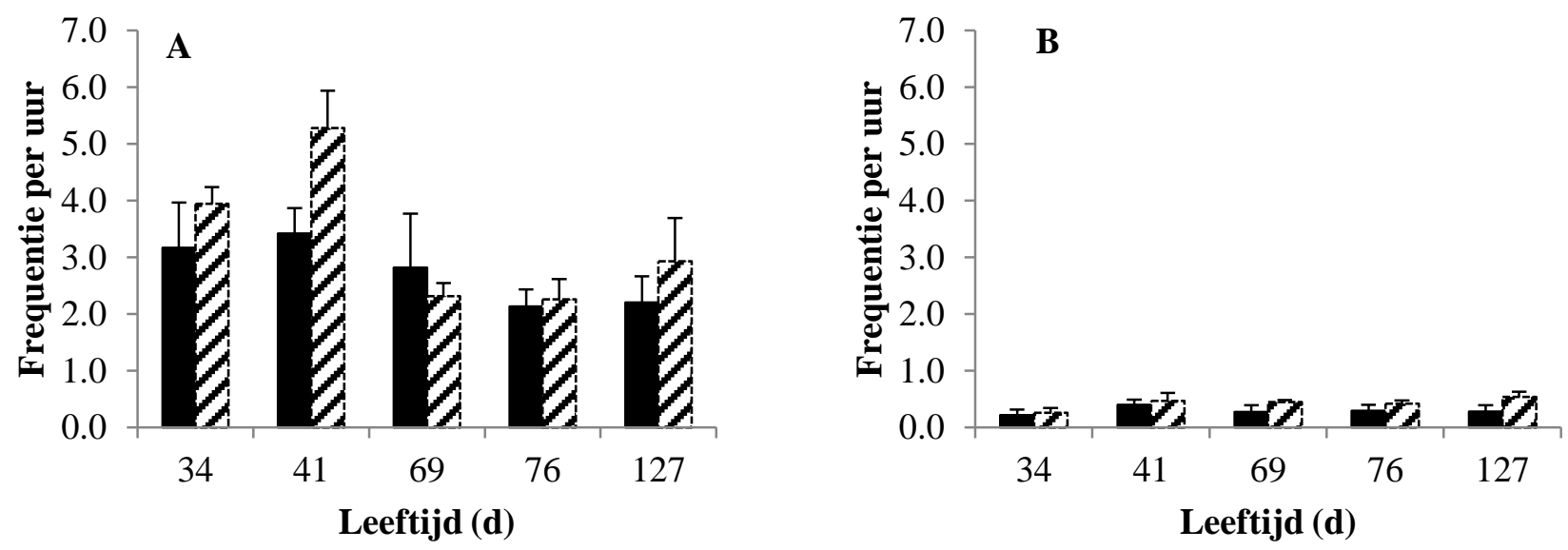

Figuur 6 Frequentie van totaal agressief gedrag (kopstoten, bijten en vechten met ander varkens en agressie bij de voerbak) (A) en agressie bij de voerbak (B) op dag 34, 41, 69, 76 en 127 bij biggen en vleesvarkens opgegroeid in een groepskraamsysteem en abrupt gespeend op 4 weken leeftijd en daarna tot 9 weken leeftijd gehuisvest in een verrijkt hok in een groep van 35 biggen (A4; gestreepte balk) of geleidelijk gespeend op 9 weken leeftijd door toepassing van intermittent suckling (IS9; zwarte balk); op een leeftijd van 9 weken zijn zowel de A4 als de IS9 biggen opgelegd in verrijkte vleesvarkenshokken voor 35 dieren. 
Uit figuur 6 blijkt dat er geen verschil was in de frequentie van totaal agressief gedrag tussen A4 en IS9 dieren. De frequentie van agressie was hoger op dag 41 dan op dag 69, 76 en $127(p<0,01)$. De frequentie van agressie aan de voerbak tendeerde naar lager bij de IS9 dieren $(p<0,10)$.

In figuur 7 is de frequentie van belly nosing op dag 34, 41, 69, 76 en 127 weergegeven.

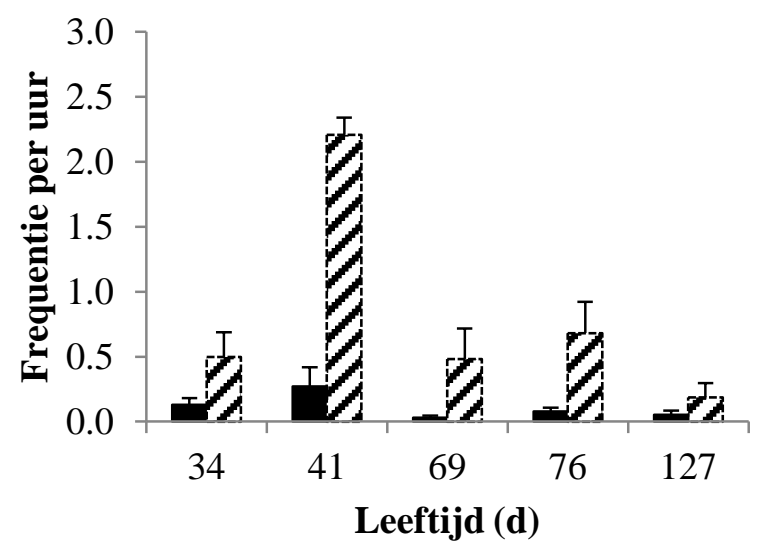

Figuur 7 Frequentie van belly nosing op dag 34, 41, 69, 76 en 127 bij biggen en vleesvarkens opgegroeid in een groepskraamsysteem en abrupt gespeend op 4 weken leeftijd en daarna tot 9 weken leeftijd gehuisvest in een verrijkt hok in een groep van 35 biggen (A4; gestreepte balk) of geleidelijk gespeend op 9 weken leeftijd door toepassing van intermittent suckling (IS9; zwarte balk); op een leeftijd van 9 weken zijn zowel de A4 als de IS9 biggen opgelegd in verrijkte vleesvarkenshokken voor 35 dieren.

Uit tabel 7 blijkt dat belly nosing meer voorkwam bij de A4 dieren dan bij IS9 dieren $(p<0,001)$. Er was een interactie tussen proefbehandeling en dag van waarnemen. Bij de IS9 dieren was de frequentie van belly nosing vergelijkbaar op alle dagen van waarnemen. Bij de A4 dieren was de frequentie van belly nosing hoger op dag 41 dan op dag 34, 69, 76 en 127.

In figuur 8 is de activiteit (staan en lopen) van de dieren op dag 34, 41, 69, 76 en 127 weergegeven.

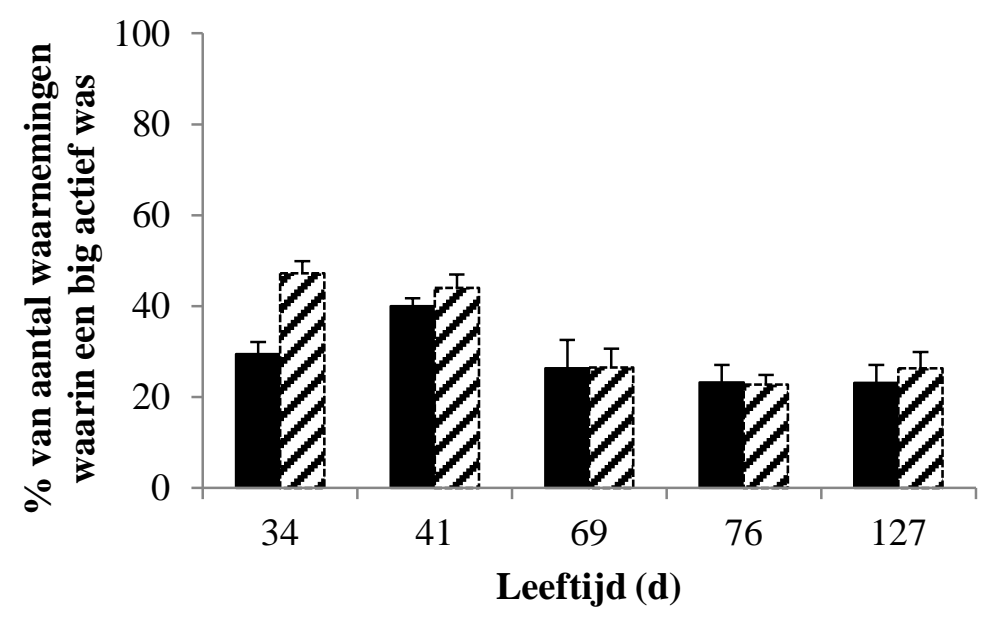

Figuur 8 Frequentie van staan en lopen (uitgedrukt als \% van aantal waarnemingen) op dag 34, 41, 69, 76 en 127 bij biggen en vleesvarkens opgegroeid in een groepskraamsysteem en abrupt gespeend op 4 weken leeftijd en daarna tot 9 weken leeftijd gehuisvest in een verrijkt hok in een groep van 35 biggen (A4; gestreepte balk) of geleidelijk gespeend op 9 weken leeftijd door toepassing van intermittent suckling (IS9; zwarte balk); op een leeftijd van 9 weken zijn zowel de A4 als de IS9 biggen opgelegd in verrijkte vleesvarkenshokken voor 35 dieren.

Uit figuur 8 blijkt dat meer A4 dan IS9 dieren actief waren tijdens de waarnemingen $(p<0,001)$. Er was een interactie tussen proefbehandeling en dag van waarnemen. Met name op dag 34 waren meer A4 biggen actief dan IS9 biggen. Op dag 41 waren meer IS9 biggen actief dan op dag 76 en 127. De A4 biggen waren actiever op dag 34 en 41 dan op dag 69, 76 en 127. 


\section{$4 \quad$ Discussie}

Doel van het onderzoek was het vergelijken van twee speenstrategieën op de ontwikkeling (groei, voeropname, gezondheid, spelgedrag en beschadigend gedrag) van biggen uit een groepskraamsysteem. In de ene groep werden de biggen abrupt gespeend op 4 weken leeftijd (A4). In de andere groep werden de biggen geleidelijk gespeend op 9 weken leeftijd door toepassing van IS (IS9). In de IS9 groep werden de zeugen van dag 28 t/m dag 34 na werpen 10 uur per dag van de biggen gescheiden door ze naar de IS-ruimte te brengen. In de IS-ruimte hadden de zeugen beercontact om de berigheid op te wekken. Van dag 35 tot dag 63 na werpen konden de zeugen zich vrijwillig van de biggen afzonderen door naar de IS-ruimte te gaan. De biggen hadden geen toegang tot de IS-ruimte. De A4 biggen bleven na spenen in een groep van 35 bij elkaar in een verrijkt hok. Op een leeftijd van 9 weken zijn zowel de A4 als de IS9 biggen opgelegd in verrijkte vleesvarkenshokken voor 35 dieren.

\section{Resultaten zeugen}

Gewicht, spekdikte en voeropname

Van werpen tot vier weken na werpen verloren de IS9 zeugen meer gewicht dan de A4 zeugen. Mogelijk komt dit door het iets hogere aantal biggen bij de IS9 zeugen (11,5 vs 12,1 biggen per zeug op 4 weken na werpen in respectievelijk de A4 en IS9 groep). Van dag 28 tot dag 63 na werpen namen de IS9 zeugen $12 \mathrm{~kg}$ toe in gewicht en verloren 0,6 $\mathrm{mm}$ spek. Het verlies aan spekdikte is mogelijk het gevolg van de melkproductie. Er zijn geen vergelijkbare studies uitgevoerd, waarin zeugen na een periode van verplichte en vrijwillige IS op 9 weken na werpen gespeend werden. In onderzoek van Van der Peet-Schwering et al. (2016) werden zeugen op 6 weken gespeend na een week verplichte IS in de vijfde week na spenen. Op 4 en 9 weken na werpen (op 9 weken na werpen waren de zeugen drie weken gespeend) is de spekdikte bij deze zeugen gemeten. De zeugen zijn niet gewogen op 9 weken na werpen. De zeugen verloren ca. $1 \mathrm{~mm}$ spek van 4 tot 9 weken na werpen. Dat is iets meer dan in ons onderzoek maar in het onderzoek van Van der Peet-Schwering et al. (2016) kregen de zeugen van 6 tot 9 weken na werpen minder voer verstrekt. In ons onderzoek kregen de zeugen van 4 tot 9 weken na werpen $7,5 \mathrm{~kg}$ voer per dag verstrekt. De biggen konden mee eten van het zeugenvoer. Het is niet bekend hoeveel zeugenvoer is opgenomen door de zeugen en hoeveel door de biggen.

\section{$\underline{\text { Uitval biggen }}$}

Zowel in de A4 als IS9 groep is ca. $23 \%$ van de biggen uitgevallen van werpen tot vier weken na werpen. Ongeveer $60 \%$ hiervan $(2,1 \mathrm{big})$ is doodgelegen door de zeug in de eerste dagen na geboorte. Er was veel variatie in uitval van biggen tussen zeugen. Van der Peet-Schwering et al. (2015) vergeleken de ontwikkeling van biggen die opgegroeid zijn in een groepskraamsysteem met de ontwikkeling van biggen die opgegroeid zijn in een traditioneel kraamhok. Het aantal uitgevallen biggen tijdens de zoogperiode, m.n. het aantal doodgelegen biggen in de eerste dagen na geboorte, was duidelijk hoger in het groepskraamsysteem (3,2 uitgevallen big per toom) dan in het traditionele kraamhok (1,5 uitgevallen big per toom) en was vergelijkbaar met het percentage uitgevallen biggen in ons onderzoek. Uit literatuuronderzoek van Van Nieuwamerongen et al. (2014) bleek ook dat het aantal doodgelegen biggen hoger is bij los werpen dan bij werpen in kraamboxen. Risicofactoren voor doodliggen zijn onder andere grote tomen, lage geboortegewichten, niet optimale inrichting van het werphok en geen goede moedereigenschappen van de zeugen. De meeste biggen in ons onderzoek zijn uitgevallen in het werphok voor het groeperen van de biggen (3,0 biggen per toom); 0,5 big per toom is uitgevallen na het groeperen van de tomen. Het doodliggen van biggen in het werphok in een groepskraamsysteem blijft een belangrijk aandachtspunt dat nog verder verbeterd moet worden. Mogelijk kan het doodliggen verminderd worden door de zeug de eerste twee à drie dagen na werpen vast te zetten.

\section{Productieresultaten volgende worp}

De zeugen uit de A4 groep, zijn allemaal binnen een week na spenen berig geworden en geïnsemineerd. Van de zeugen uit de IS9 groep is $79 \%$ ( $20 \%$ in ronde $1,80 \%$ in ronde 2 en $100 \%$ in ronde 3, 4 en 5) binnen een week na de start van de verplichte IS berig geworden. Dit percentage is vergelijkbaar met de resultaten zoals gevonden door Van der Peet-Schwering et al. (2016). In hun 
onderzoek werd $77 \%$ van de zeugen berig binnen een week na de start van IS. In het onderzoek van Van der Peet-Schwering et al. (2015 $)$ werd $88 \%$ van de zeugen berig binnen een week na de start van IS. In ons onderzoek werd in ronde 1 slechts één van de vijf zeugen berig tijdens de verplichte IS. In ronde 1 was de beer tijdens de verplichte IS continue in de IS-ruimte aanwezig. Continu beercontact kan de bronstexpressie van de zeugen negatief beïnvloeden als gevolg van gewenning aan de geur en geluiden van de beer (Tilbrook and Hemsworht, 1990). In ronde $2 \mathrm{t} / \mathrm{m} 5$ is dit aangepast en was de beer alleen tijdens de eerste twee dagen van de verplichte IS continue in de ISruimte aanwezig. Op dag 3 en 4 van de verplichte IS was de beer alleen 's ochtends drie uur aanwezig in de IS-ruimte en op dag 5 en 6 zowel 's ochtends als 's middags 3 uur. In ronde 2 t/m 5 zijn 18 van de 19 zeugen berig geworden tijdens de verplichte IS. De gewijzigde strategie lijkt dus een positief effect te hebben gehad op het aantal zeugen dat berig werd binnen een week na de start van IS. Het afbigpercentage van $1^{\text {ste }}$ inseminatie van de zeugen die geïnsemineerd zijn tussen dag 28 en dag 35 na werpen (zie tabel 3) was vergelijkbaar in de A4 en IS9 groep (ca. 90\%). In het onderzoek van Van der Peet-Schwering et al. (2016) was het afbigpercentage van $1^{\text {ste }}$ inseminatie ook ca. $90 \%$ als de zeugen $3,5 \mathrm{~kg}$ voer per dag kregen vanaf spenen (zeugen waren toen 9 dagen drachtig) tot 34 dagen dracht. Bij de zeugen die $2,8 \mathrm{~kg}$ voer per dag kregen in deze periode was het afbigpercentage van $1^{\text {ste }}$ inseminatie ca. $80 \%$. Voor een hoog afbigpercentage van $1^{\text {ste }}$ inseminatie bij zeugen die tijdens de lactatie geïnsemineerd worden, is het dus belangrijk dat de zeugen voldoende voer krijgen tijdens de eerste maand van de dracht. Het aantal levend geboren biggen in de volgende worp in de A4 en IS9 groep was respectievelijk 15,6 en 16,5 en was daarmee iets hoger dan het aantal levend geboren biggen in de voorgaande worp. Het spenen van de zeugen op 9 weken na werpen in combinatie met IS en inseminatie tijdens de lactatie heeft de reproductie resultaten van de zeugen in ronde $2 \mathrm{t} / \mathrm{m} 5$ dus niet verslechterd in vergelijking met abrupt spenen op 4 weken na werpen.

\section{Geleidelijk spenen IS9 biggen}

Om na te gaan of de biggen geleidelijk gespeend werden tijdens de lactatie van 9 weken, is de zoogfrequentie van de biggen wekelijks vastgelegd. Op dag 21 van de lactatie hadden de biggen ca. 1 succesvolle zoogbeurt per uur. In onderzoek van Bohnenkamp et al. (2013) was het aantal succesvolle zoogbeurten op dag 22 van de lactatie in een groepskraamsysteem met zes zeugen en haar biggen iets lager dan in ons onderzoek, namelijk 0,7 per dag. In ons onderzoek was de MS-ruimte $31 \mathrm{~m}^{2}$ voor vijf zeugen en haar biggen terwijl de MS-ruimte in het onderzoek van Bohnenkamp et al. (2013) 13 $\mathrm{m}^{2}$ was voor zes zeugen en haar biggen. In ons onderzoek hadden de zeugen dus meer ruimte om ongestoord te kunnen zogen en dit verklaart mogelijk het hogere aantal zoogbeurten.

Tijdens de verplichte IS in week 5 van de lactatie (de zeugen waren 10 uur per dag gescheiden van de biggen) daalde het aantal succesvolle zoogbeurten naar 0,7 per uur. Berkeveld et al. (2007) vonden een vergelijkbaar aantal zoogbeurten tijdens IS waarbij individueel gehuisveste zeugen gedurende 12 uur per dag gescheiden werden van de biggen. Tijdens de vrijwillige IS, waarin de zeugen de biggen vrijwillig konden verlaten, daalde het aantal succesvolle zoogbeurten van 0,9 per uur op dag 35 na werpen tot 0,4 per uur op dag 56 na werpen. De biggen werden dus geleidelijk gespeend.

\section{Ontwikkeling biggen 4 tot 9 weken leeftijd}

De IS9 biggen groeiden sneller van dag 28 tot dag 33 dan de A4 biggen (305 vs $179 \mathrm{~g} / \mathrm{d}$ ). Bij de IS9 biggen was er geen dip in de groei als gevolg van de verplichte IS (groei van geboorte tot dag 28 en van dag 28 tot 33 was respectievelijk 218 en $305 \mathrm{~g} / \mathrm{d}$ ), terwijl er bij de A4 biggen wel sprake was van een dip in de groei na spenen (groei van geboorte tot dag 28 en van dag 28 tot 33 was respectievelijk 215 en $179 \mathrm{~g} / \mathrm{d})$. Berkeveld et al. $\left(2007^{\mathrm{a}}\right.$ ) zagen wel een groeidip na de start van IS, maar de groeidip was lager dan bij biggen die gespeend werden. Ook in onderzoek van Van der Peet-Schwering et al. $\left(2015^{a}\right.$; 2016) was er sprake van een groeidip na de start van IS. In hun onderzoek groeiden de biggen tijdens de verplichte IS van dag 27 tot $34 \mathrm{ca} .160 \mathrm{~g} / \mathrm{d}$ terwijl ze van dag 0 tot dag $27 \mathrm{ca} .240$ $\mathrm{g} / \mathrm{d}$ groeiden. Van der Peet-Schwering et al. $\left(2015^{\mathrm{a}} ; 2016\right)$ gaven aan dat de daling in groei het gevolg was van de lage voeropname van de biggen tijdens de IS periode. In ons onderzoek namen de IS9 biggen van dag 28 tot dag 33 ook duidelijk minder biggenvoer op dan de A4 biggen, maar ze konden naast het biggenvoer en zeugenmelk (in de tijd dat de zeug aanwezig was), ook zeugenvoer opnemen. Van dag 33 tot dag 63 groeiden de IS9 biggen $40 \mathrm{~g} / \mathrm{d}$ sneller dan de A4 biggen, maar dit verschil in groei was niet significant $(p=0,25)$. De A4 biggen lijken dan dus hersteld te zijn van de groeidip in de eerste week na spenen.

Het percentage IS9 biggen met diarree op dag 33 en dag 40 was lager dan het percentage A4 biggen met diarree ( 12,5 vs 33\%). Mogelijk was de reductie in lengte van de darmvilli minder bij de IS9 
biggen dan bij de A4 biggen. Uit onderzoek van Berkeveld et al. (2009) bleek dat er een significante verkorting van de darmvilli was in de eerste week na spenen bij biggen die op dag 26 abrupt gespeend werden terwijl dit niet het geval was bij biggen die op dag 26 gespeend werden na een week IS. Kortere darmvilli zijn geassocieerd met een grotere kans op diarree als gevolg van een verminderde absorptiecapaciteit in de dunne darm (Nabuurs et al., 1993). In de IS9 groep zijn wel meer biggen behandeld vanwege beenwerkaandoeningen dan in de A4 groep (respectievelijk 7,6 en $4,1 \%$ van de biggen; $p=0,13$ ). De reden hiervoor is niet helemaal duidelijk. Mogelijk speelt de grootte van de MS-ruimte die de biggen ter beschikking hadden (de biggen hadden veel ruimte om rond te rennen) hierin een rol.

De A4 biggen vertoonden meer belly nosing (het wrijven van de buik van een ander varken via het op en neer bewegen van de snuit) dan de IS9 biggen. Bij de A4 biggen was er een piek in de frequentie van belly nosing op dag 41 terwijI bij de IS9 biggen de frequentie relatief laag en constant was. Een piek in belly nosing in de eerste weken na spenen en vervolgens een daling is vaker gevonden (Gonyou et al., 1998). Belly nosing wordt gezien als een vorm van zooggedrag en wordt uitgevoerd om aan de zoogbehoefte te voldoen (Widowski et al., 2008). De ontwikkeling van belly nosing hangt af van hoe soepel de overgang van zeugenmelk naar vast voer verloopt (Widowski et al., 2008). De lagere frequentie van belly nosing bij de IS9 biggen geeft aan dat de overgang van zeugenmelk naar vast voer mogelijk soepeler is verlopen bij de IS9 biggen dan bij de A4 biggen.

Bij de A4 biggen was er op dag 41, naast de piek in belly nosing, ook een piek in de frequentie van agressief gedrag. Mogelijk is dit het gevolg van de verandering in groepssamenstelling bij spenen en moest de hiërarchie opnieuw vastgesteld worden. Bij de IS9 biggen was er op dag 41 geen verandering in groepssamenstelling. De hogere frequentie van agressief gedrag en van belly nosing bij de A4 biggen, samen met de hogere frequentie van oraal manipulatief gedrag kunnen ook duiden op meer stress bij de A4 biggen als gevolg van spenen (Dybkjær, 1992).

Geconcludeerd kan worden dat de A4 biggen langzamer groeiden van dag 28 tot dag 33 dan de IS9 biggen. Daarnaast was het percentage biggen met diarree en de frequentie van belly nosing, agressief gedrag en oraal manipulatief gedrag hoger bij de A4 biggen.

\section{Ontwikkeling vleesvarkens}

Op 9 weken leeftijd zijn zowel de A4 als de IS9 biggen opgelegd in verrijkte vleesvarkenshokken. De IS9 biggen werden op dat moment gespeend. Van dag 63 tot dag 68 namen de IS9 vleesvarkens evenveel voer op als de A4 vleesvarkens en hadden een vergelijkbare groei. Er lijkt dus geen sprake geweest te zijn van een speendip bij de IS9 vleesvarkens. Het geleidelijk spenen van de biggen op 9 weken leeftijd waarbij de zoogfrequentie geleidelijk afnam en de opname van vast voer geleidelijk toenam is waarschijnlijk de reden dat er geen sprake was van een speendip. Een geleidelijke opname van vast voer is belangrijk voor een succesvolle adaptatie van het maagdarmkanaal aan vast voer (Miller and Slade, 2003). Ook de hogere leeftijd van de IS9 biggen bij spenen kan een rol hebben gespeeld omdat de rijpheid van het maagdarmkanaal toeneemt met het ouder worden van de dieren (Miller and Slade, 2003). Van opleg op 9 weken leeftijd tot afleveren waren er geen verschillen in voeropname, groei, voederconversie en slachtkwaliteit tussen de A4 en IS9 vleesvarkens. Bij opleg waren de IS9 vleesvarkens 2,7 kg zwaarder. Deze voorsprong in gewicht hebben ze behouden tijdens de vleesvarkensfase waardoor ze een paar dagen eerder geleverd konden worden en iets zwaarder waren bij afleveren. Van 5 tot 9 weken leeftijd was er een tendens tot een ongunstigere voederconversie en een lagere groei bij de IS9 vleesvarkens. Dit werd m.n. gevonden in ronde 2 en 3 en in mindere mate in ronde 4. De reden hiervoor is niet duidelijk. Van 9 weken tot afleveren tot afleveren waren er geen verschillen in groei en voederconversie tussen de A4 en IS9 vleesvarkens.

Het geleidelijk spenen van de biggen op 9 weken leeftijd heeft niet geresulteerd in minder vleesvarkens met diarree op dag 68 en 75 in vergelijking met de A4 vleesvarkens. Het aantal dagen dat de vleesvarkens diarree hadden was echter lager bij de IS9 varkens dan bij de A4 varkens. Ook de gemiddelde diarreescore was lager (d.w.z. meer normale mest) bij de IS9 varkens dan bij de A4 varkens. In de A4 groep zijn meer dieren uitgevallen dan in de IS groep ( 11 versus 5 dieren; $p=$ 0,13 ). Met name in ronde 3 zijn er meer A4 dan IS9 vleesvarkens uitgevallen ( 5 versus 0 dieren). De reden hiervoor is niet duidelijk. 
Bij de IS9 vleesvarkens was er na spenen geen piek in de frequentie van belly nosing en agressief gedrag zoals te zien was bij de A4 biggen op 14 dagen na spenen. Ook was er geen toename van oraal manipulatief gedrag. Dit duidt op minder stress als gevolg van spenen (Dybkjær, 1992) van de IS9 dieren dan van de A4 dieren. Gedurende het vleesvarkenstraject vertoonden de IS9 vleesvarkens minder oraal manipulatief gedrag dan de A4 vleesvarkens. Ook de oorbeschadigingsscore op dag 126 was lager bij de IS9 vleesvarkens dan bij de A4 vleesvarkens en ze hadden minder krassen. Daarnaast was de frequentie van belly nosing gedurende het vleesvarkenstraject lager bij de IS9 vleesvarkens dan bij de A4 vleesvarkens. Dit duidt op minder stress (Schrøder-Petersen and Simonsen, 2001) bij de IS9 vleesvarkens dan bij de A4 vleesvarkens en geeft aan dat de overgangen op 4 en 9 weken leeftijd geleidelijker zijn verlopen bij de IS9 vleesvarkens dan bij de A4 vleesvarkens.

De verschillen in gedrag tussen de IS9 en A4 vleesvarkens geven daarnaast aan dat de effecten van abrupt spenen op 4 weken leeftijd of geleidelijk spenen op 9 leeftijd ook op de lange termijn nog zichtbaar zijn.

Geconcludeerd kan worden dat er bij de IS9 vleesvarkens geen sprake was van een speendip en dat ze minder gedrag (zoals oraal manipulatief gedrag en belly nosing) vertoonden dat wijst op stress als gevolg van spenen. 


\section{Conclusies}

Op Varkens Innovatie Centrum Sterksel is de ontwikkeling (groei, voeropname, gezondheid, spelgedrag en beschadigend gedrag) van biggen uit een groepskraamsysteem onderzocht bij abrupt spenen op 4 weken leeftijd(A4) of bij geleidelijk spenen op 9 weken door toepassing van intermittent suckling (IS9). De belangrijkste conclusies uit dit onderzoek zijn:

- Zowel in de A4 als de IS9 groep is een hoog percentage (ca. 23\%) van de biggen uitgevallen van werpen tot vier weken na werpen. Circa $60 \%$ hiervan is doodgelegen door de zeug in de eerste dagen na werpen. De overige biggen zijn uitgevallen vanwege laag geboortegewicht, spreidzit en diverse redenen. De meeste biggen zijn uitgevallen in het werphok voor het groeperen van de biggen ( 3,0 biggen per toom); 0,5 big per toom is uitgevallen na het groeperen van de tomen.

- De zeugen uit de A4 groep zijn allemaal binnen een week na spenen berig geworden en geïnsemineerd. Van de zeugen uit de IS9 groep is $79 \%$ (20\% in ronde $1,95 \%$ in ronde $2 \mathrm{t} / \mathrm{m}$ 5 ) binnen een week na de start van de verplichte IS berig geworden. Na ronde 1 is het aantal uren beercontact per dag gewijzigd. Het afbigpercentage van 1ste inseminatie van de zeugen die geïnsemineerd zijn tussen dag 28 en dag 35 na werpen was $90 \%$ in zowel de A4 als de IS9 groep. Het totaal aantal geboren biggen in de volgende worp in de A4 en IS 9 groep was respectievelijk 17,4 en 17,7. Het spenen van de zeugen op 9 weken na werpen in combinatie met IS en inseminatie tijdens de lactatie heeft de reproductie resultaten van de zeugen in ronde $2 \mathrm{t} / \mathrm{m} 5$ dus niet verslechterd in vergelijking met abrupt spenen op 4 weken na werpen.

- De zoogfrequentie bij de IS9 biggen daalde van 26,4 zoogbeurten per 24 uur op dag 21 na werpen tot 10,1 zoogbeurten per 24 uur op dag 56 na werpen. De IS9 biggen werden dus geleidelijk gespeend.

- $\quad$ Het effect van spenen op de A4 biggen was in dit onderzoek groter dan het effect van IS (verplichte IS in de vijfde week na werpen en daarna vrijwillige IS, waarin de zeugen de biggen vrijwillig konden verlaten) op de IS9 biggen. Dit blijkt uit een lagere groei van dag 28 tot 33 van de A4 biggen in vergelijking met de IS 9 biggen ( $179 \mathrm{vs} 305 \mathrm{~g} / \mathrm{d}$ ), een hoger percentage A4 biggen met diarree op dag 33 en dag 40 ( 33 vs $12,5 \%$ ), een hogere frequentie van belly nosing bij de A4 biggen, een piek in belly nosing en in agressief gedrag op dag 41 bij de A4 biggen en een hogere frequentie van oraal manipulatief gedrag bij de A4 biggen.

- $\quad$ Van dag 28 tot 63 groeiden de IS9 biggen $50 \mathrm{~g} / \mathrm{d}(p=0,12)$ meer dan de A4 biggen terwijl ze duidelijk minder biggenvoer opnamen $(0,33 \mathrm{vs} 0,67 \mathrm{~kg} / \mathrm{d})$. De IS9 biggen konden ook melk bij de zeug en zeugenvoer opnemen. De opname van zeugenmelk en zeugenvoer door de biggen is niet bekend. Het percentage uitgevallen biggen van dag 28 tot 63 was vergelijkbaar in de A4 en IS9 groep.

- Van dag 63 tot dag 68 namen de IS9 vleesvarkens evenveel voer op als de A4 vleesvarkens en hadden een vergelijkbare groei. Er lijkt dus geen sprake geweest te zijn van een speendip bij de IS9 vleesvarkens. Van dag 63 tot afleveren waren er geen verschillen in voeropname, groei, voederconversie en slachtkwaliteit tussen de A4 en IS9 vleesvarkens.

- $\quad$ Bij de IS9 vleesvarkens was er na spenen geen piek in de frequentie van belly nosing en agressief gedrag zoals te zien was bij de A4 biggen op 14 dagen na spenen. Ook was er geen toename van oraal manipulatief gedrag. Dit duidt op minder stress als gevolg van spenen bij de IS9 dieren dan bij de A4 dieren.

- Gedurende het vleesvarkenstraject vertoonden de IS9 vleesvarkens minder oraal manipulatief gedrag en belly nosing dan de A4 vleesvarkens. Dit duidt op minder stress bij de IS9 vleesvarkens dan bij de A4 vleesvarkens. De verschillen in gedrag tussen de IS9 en A4 vleesvarkens geven aan dat de effecten van abrupt spenen op 4 weken leeftijd of geleidelijk spenen op 9 leeftijd ook op de lange termijn nog zichtbaar zijn.

Op basis van dit onderzoek kan geconcludeerd worden dat de IS9 varkens beter konden omgaan met de overgangen op 4 en 9 weken leeftijd dan de A4 varkens. Bij de IS9 varkens was er geen sprake van een speendip en ze vertoonden minder gedrag dat wijst op stress als gevolg van spenen (zoals oraal manipulatief gedrag en belly nosing). Geleidelijk spenen op 9 weken leeftijd lijkt in groepskraamsystemen een goede strategie om de speendip te voorkomen en het gedrag van de biggen en vleesvarkens te verbeteren. Het doodliggen van biggen in het werphok in de eerste dagen na geboorte is een belangrijk aandachtspunt dat verder verbeterd moet worden. 


\section{Literatuur}

Berkeveld, M., P. Langendijk, J.E. Bolhuis, A.P. Koets, J.H.M. Verheijden, M.A.M. Taverne. 2007. Intermittent suckling during an extended lactation period: Effects on piglet behaviour. Journal of Animal Science, 85, 3415-3424.

Berkeveld, M., P. Langendijk, N.M. Soede, B. Kemp, M.A.M. Taverne, J.H.M. Verheijden, N. Kuijken and A.P. Koets. 2009. Improving adaptation to weaning: effect of intermittent suckling regimens on piglet feed intake, growth and gut characteristics. J ournal of Animal Science, 87, 3156-3166.

Berkeveld, M., P. Langendijk, H.M.G. van Beers-Schreurs, A.P. Koets, M.A.M. Taverne and J.H.M. Verheijden. $2007^{\mathrm{a}}$. Postweaning growth check in pigs is markedly reduced by intermittent suckling and extended lactation. J ournal of Animal Science, 85, 258-266.

Bohnenkamp, A.L., C. Meyer, K. Müller and J. Krieter. 2013. Group housing with electronically controlled crates for lactating sows. Effect on farrowing, suckling and activity behaviour of sows and piglets. Applied Animal Behaviour Science, 145, 37-43.

Dybkjær, L., 1992. The identification of behavioural indicators of 'stress' in early weaned piglets. Applied Animal Behaviour Science, 35, 135-147.

Genstat. 2013. GenStat for Windows $16^{\text {th }}$ Edition. VSN International Ltd., Hemel Hempstead, UK.

Gonyou, H.W., E. Beltranena, D.L. Whittington and J.F. Patience. 1998. The behaviour of pigs weaned at 12 and 21 days of age from weaning to market. Canadian Journal of Animal Science, 78, 517-523.

Miller, H. and R. Slade. 2003. Digestive physiology of the weaned pig. In: Pluske, J., J. Le Dividich and M. Verstegen (Eds.). Weaning the pig: concept and consequences.

Nabuurs, M.J.A., A. Hoogendoorn, E.J. van der Molen and A.L.M. van Osta. 1993. Villus height and crypt depth in weaned and unweaned pigs, reared under various circumstances in the Netherlands. Research in Veterinary Science, 55, 78-84.

Nieuwamerongen, S.E. van, C.M.C. van der Peet-Schwering, A.I.J. Hoofs, N.M. Soede en J.E. Bolhuis. 2014. Literatuuronderzoek naar groepshuisvesting van kraamzeugen en hun biggen. Rapport 757, Wageningen UR Livestock Research, Wageningen.

Nieuwamerongen, S.E. van, N.M. Soede, C.M.C. van der Peet-Schwering, B. Kemp and J.E. Bolhuis. 2015. Development of piglets raised in a new multi-litter housing system vs. conventional single-litter housing until 9 week of age. Journal of Animal Science, 93, 5442-5454.

Oostindjer, M., H. van den Brand, B. Kemp and J.E. Bolhuis. 2011. Effects of environmental enrichment and loose housing of lactating sows on piglet behaviour before and after weaning. Applied Animal Behaviour Science, 134, 31-41.

Peet-Schwering, C.M.C. van der, S.E. van Nieuwamerongen, J.E. Bolhuis, L.M.P. Troquet, A. Hoofs en N.M. Soede. 2015. Groepskraamsysteem: analyse van de ontwikkeling van zeugen, biggen en vleesvarkens. Rapport 880, Wageningen Livestock Research, Wageningen.

Peet-Schwering, C.M.C. van der, J.M. Rommers, L.M.P. Troquet, N.M. Soede. $2015^{a}$. Effect van voerniveau bij drachtige lacterende zeugen op reproductie en conditie. Rapport 861, Wageningen Livestock Research, Wageningen. 
Peet-Schwering, C.M.C. van der, R. Verheijen, G.P. Binnendijk, N.M. Soede. 2016. Effect van voersamenstelling bij drachtige lacterende zeugen en voerniveau begin dracht op reproductie en conditie. Rapport 952, Wageningen Livestock Research, Wageningen.

Schrøder-Petersen, D.L. and H.B. Simonsen. 2001. Tail biting in pigs. The Veterinary J ournal, 162, 196-210.

Tilbrook, A. J. and P.H. Hemsworth. 1990. Detection of oestrus in gilts housed adjacent or opposite boars or exposed to exogenous boar stimuli. Applied Animal Behaviour Science, 28, 3, 233-245.

Widowski, T.M., S. Torrey, C.J. Bench and H.W. Gonyou. 2008. Development of ingestive behaviour and the relationship to belly nosing in early-weaned piglets. Applied Animal Behaviour Science, 110, 109-127. 


\section{Bijlage 1 Protocol beschadigingen biggen}

Oorbeschadigingen: score per oor ten gevolge van manipulatie (alleen de achterkant van elk oor, m.n. naar punt en basis kijken):
0 . Geen beschadigingen
1. Kleine bijtpuntjes zijn zichtbaar, oor is intact
2. Kleine wond, oor is intact
3. Medium wond, oor is intact
4. Ernstige wond, deel van oor mist

\section{Staartbeschadigingen:}

0 . Geen beschadigingen.

1. Kleine beschadigingen (krasjes) of bijtpuntjes ter grootte van een speldenknop zijn zichtbaar.

2. Kleine wond: duidelijk zichtbare wond aan het uiteinde van de staart. De staart is niet verkort door de beschadiging.

3. Medium wond: duidelijk zichtbare wond op de staart. De staart is gedeeltelijk verkort.

Huidbeschadigingen: het aantal diepe en oppervlakkige krassen is gescoord voor, midden en achter op het dier. Voor de beoordeling van de huidbeschadigingen wordt het lichaam van het varken verdeeld in voor, midden, achter (zie onderstaande figuur). De beschadigingen aan de linker- en rechterzijde van het dier worden als één geheel beoordeeld.
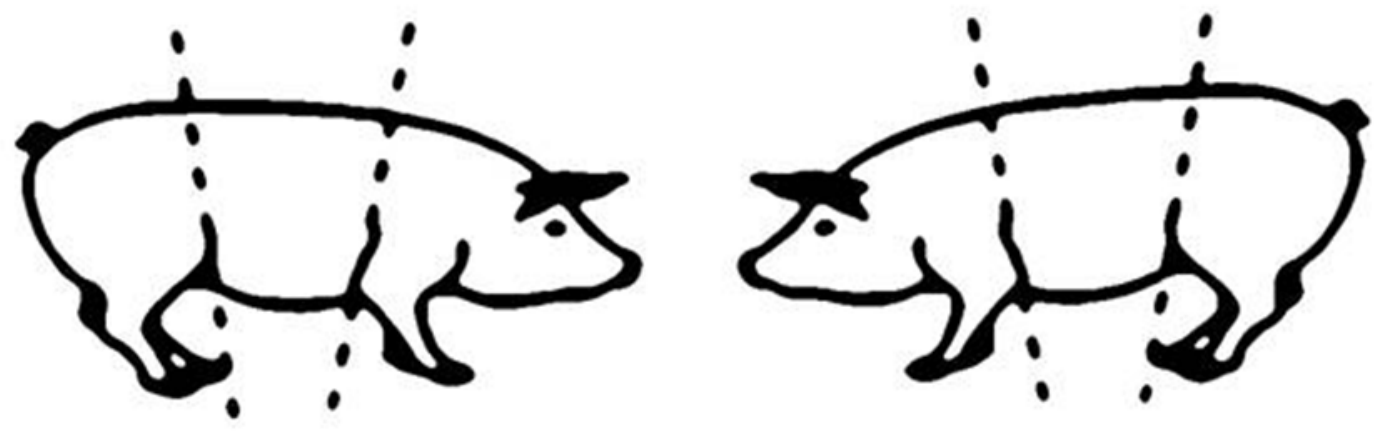


\section{Bijlage 2 Protocol gedragswaarnemingen}

\begin{tabular}{|c|c|}
\hline Gedrag & Omschrijving \\
\hline \multicolumn{2}{|l|}{ Spelgedrag } \\
\hline Individual play & $\begin{array}{l}\text { Scampering (forward hops in rapid succession), turning (rapid turn on } \\
\text { the spot), head tossing, flopping (rapid drop from an upright position } \\
\text { to lying), rolling on back, sliding, running across pen individually }\end{array}$ \\
\hline Social play ( 2 pigs or more) & $\begin{array}{l}\text { Nudging (play invitation: gentle pushing of opponent), gamboling } \\
\text { (running across pen together), play fighting, scampering together }\end{array}$ \\
\hline Substrate play & $\begin{array}{l}\text { Shaking of head while holding material (e.g. straw, rope, manure) that } \\
\text { protrudes from mouth (not scored when only chewing on material) }\end{array}$ \\
\hline \multicolumn{2}{|l|}{ Manipulatief gedrag } \\
\hline Manipulating ears & Nibbling, sucking or chewing an ear of another piglet \\
\hline Manipulating tails & Nibbling, sucking or chewing the tail of another piglet \\
\hline Manipulating sow* & Nibbling, sucking or chewing part of the body of the sow \\
\hline Manipulating other & $\begin{array}{l}\text { Nibbling, sucking or chewing another part of the body of another } \\
\text { piglet, e.g. a paw ('hair sucking/nibbling' not scored) }\end{array}$ \\
\hline Belly nosing & $\begin{array}{l}\text { Rubbing belly of another pig with up and down snout movements ( } \geq 3 \\
\text { up AND down movements). Belly sucking/manipulation is scored } \\
\text { separately. }\end{array}$ \\
\hline \multicolumn{2}{|l|}{ Agressief gedrag } \\
\hline Head knocking & $\begin{array}{l}\text { Horizontal or vertical knocking with the head or forward thrusting with } \\
\text { the snout toward another piglet (single event or short series of events) }\end{array}$ \\
\hline Biting & Biting another piglet (single event or short series of events) \\
\hline Fighting & $\begin{array}{l}\text { Intense mutual ramming or pushing (parallel or antiparallel), with or } \\
\text { without biting, in rapid succession }\end{array}$ \\
\hline Aggression at feeder & $\begin{array}{l}\text { Feed-related aggression: Push, head knock or bite given at feeder (not } \\
\text { scored when e.g. a pig gives a head knock at the feeder resulting from } \\
\text { tail/ear biting/belly nosing) }\end{array}$ \\
\hline \multicolumn{2}{|l|}{ Activiteit } \\
\hline Inactive lying & Lying without performing any other behavior \\
\hline Active lying & $\begin{array}{l}\text { Lying while performing other behavior (such as substrate chewing, } \\
\text { sniffing the floor or manipulation) }\end{array}$ \\
\hline Active & Standing or walking \\
\hline
\end{tabular}




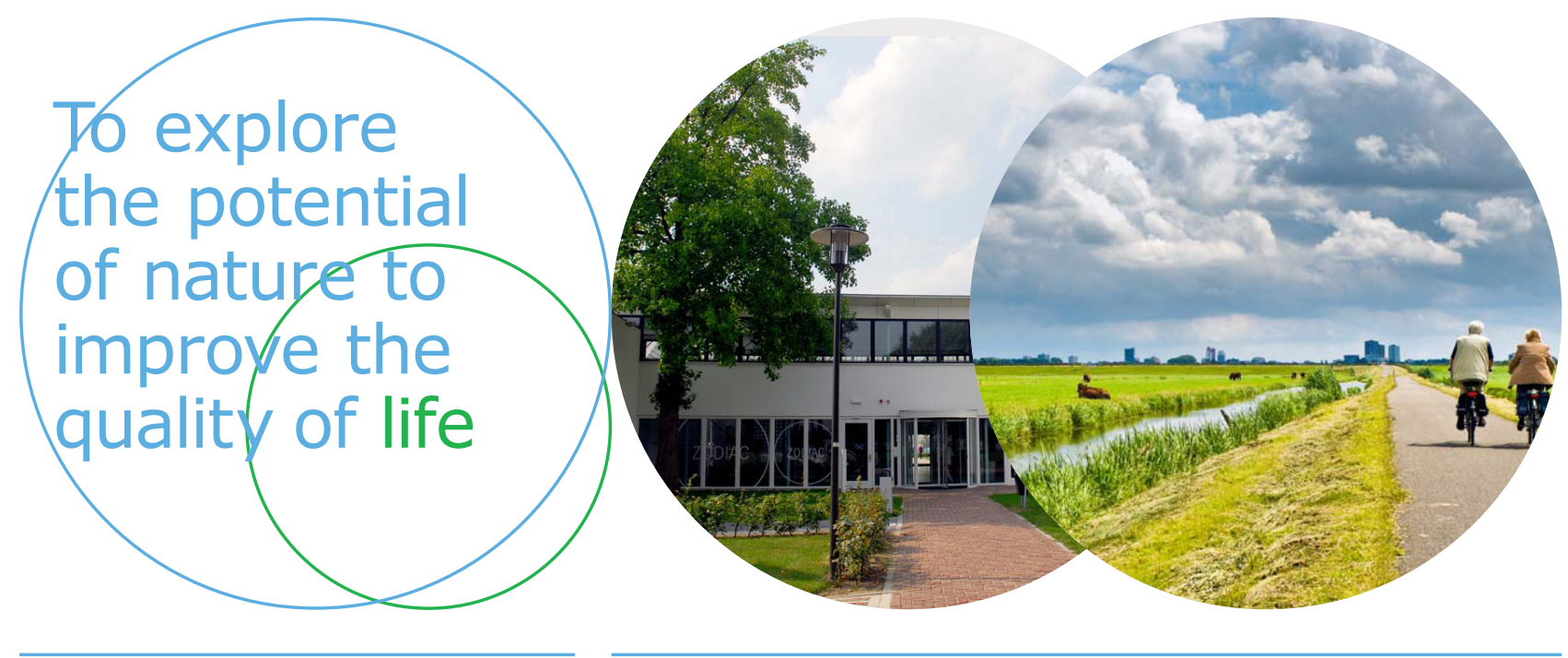

Wageningen Livestock Research Postbus 338

$6700 \mathrm{AH}$ Wageningen

T 0317483953

E info.livestockresearch@wur.nl www.wur.nl/livestock-research
Wageningen Livestock Research ontwikkelt kennis voor een zorgvuldige en renderende veehouderij, vertaalt deze naar praktijkgerichte oplossingen en innovaties, en zorgt voor doorstroming van deze kennis. Onze wetenschappelijke kennis op het gebied van veehouderijsystemen en van voeding, genetica, welzijn en milieu-impact van landbouwhuisdieren integreren we, samen met onze klanten, tot veehouderijconcepten voor de $21 \mathrm{e}$ eeuw.

De missie van Wageningen University \& Research is 'To explore the potential of nature to improve the quality of life'. Binnen Wageningen UR bundelen 9 gespecialiseerde onderzoeksinstituten van stichting DLO en Wageningen University hun krachten om bij te dragen aan de oplossing van belangrijke vragen in het domein van gezonde voeding en leefomgeving. Met ongeveer 30 vestigingen, 6.000 medewerkers en 10.000 studenten behoort Wageningen UR wereldwijd tot de aansprekende kennisinstellingen binnen haar domein. De integrale benadering van de vraagstukken en de samenwerking tussen verschillende disciplines vormen het hart van de unieke Wageningen aanpak. 